\title{
EMPLOXMENT PROTECTION LEGISLATION AND LABOR COURT ACTIVITY IN SPAIN
}

Juan F Jimeno Marta Mantinez-Matute and Juan S. Mora Sanguinetti

Documentos de Trabajo. N. 1507

\section{baneodespaña}

\section{5}

Eurosistema 
EMPLOYMENT PROTECTION LEGISLATION AND LABOR COURT ACTIVITY IN SPAIN 
EMPLOYMENT PROTECTION LEGISLATION AND LABOR

COURT ACTIVITY IN SPAIN ${ }^{(*)}$

\author{
Juan F. Jimeno \\ BANCO DE ESPAÑA, CEPR, and IZA.
}

Marta Martínez-Matute, and Juan S. Mora-Sanguinetti

BANCO DE ESPAÑA

(*) We are grateful to Justin McCrary, Ildefonso Villán Criado, Ernesto Villanueva, Cristina Barceló, María Teresa Moyna López, Paulino Font, Pablo Gimeno, Mario Izquierdo, Mariusz Golecki and participants at the $\vee$ Annual Conference of the Spanish Association of Law and Economics, the XXXIX Conference of the Spanish Economic Association, and seminars at the Banco de España and the University of Nuremberg. Patricia Festa Secanella provided excellent research assistance. 
The Working Paper Series seeks to disseminate original research in economics and finance. All papers have been anonymously refereed. By publishing these papers, the Banco de España aims to contribute to economic analysis and, in particular, to knowledge of the Spanish economy and its international environment.

The opinions and analyses in the Working Paper Series are the responsibility of the authors and, therefore, do not necessarily coincide with those of the Banco de España or the Eurosystem.

The Banco de España disseminates its main reports and most of its publications via the Internet at the following website: http://www.bde.es.

Reproduction for educational and non-commercial purposes is permitted provided that the source is acknowledged.

C BANCO DE ESPAÑA, Madrid, 2015

ISSN: 1579-8666 (on line) 


\section{Abstract}

Labor courts may introduce a significant wedge between "legal" firing costs and "effective" (post-trial) firing costs. Apart from procedural costs, there is uncertainty over judges' rulings, in particular over the likelihood of a "fair" dismissal ultimately being ruled as "unfair", which may increase firing costs significantly. In 2010 and 2012, reforms of Employment Protection Legislation widened the definition of fair economic dismissals in Spain. In this paper we look at Labor Court rulings on dismissals across Spanish provinces before and after the EPL reforms (2004-2014). We make this comparison taking into account a set of co-variates (local labor market conditions, characteristics of the Labor Courts, pre-trial conciliations, congestion of Labor Courts) which may determine the selection of dismissal cases ruled by Labor Courts. Our results suggest that, despite the 2010 and 2012 EPL reforms, the proportion of economic redundancies being ruled as fair by Labor Courts has not substantially increased, although it is now less negatively associated with the local unemployment rate than in the pre-reform period.

Keywords: employment protection legislation, firing costs, unemployment.

JEL classification: J52, J53, K31, K41. 


\section{Resumen}

La intervención de los juzgados de lo Social en casos de despido da lugar a que pueda existir una diferencia importante entre las indemnizaciones por despido establecidas por la ley y los costes efectivos de despido (después de su resolución). Además de los costes asociados al procedimiento judicial, están los derivados de la incertidumbre sobre el sentido de la sentencia, que puede declarar el despido improcedente, lo que implica una subida sustancial de las indemnizaciones. En 2010 y 2012 sendas reformas laborales ampliaron la definición de despido objetivo procedente en España. En este artículo se usan datos provinciales sobre sentencias judiciales en casos de despido referidos a períodos anteriores y posteriores a la reforma (2004-2014). En este análisis se tienen en cuenta algunas características provinciales (las condiciones locales del mercado de trabajo, características de los juzgados de lo Social, la prevalencia de conciliaciones judiciales, la congestión judicial) que pueden influir en la selección de casos de despido que acaban siendo resueltos por sentencia judicial. Los resultados indican que, a pesar de las reformas de 2010 y 2012, la proporción de despidos que son declarados procedentes por los juzgados de lo Social no ha aumentado significativamente, aunque ahora muestra una asociación negativa con la tasa de paro local menor que en el periodo anterior a las reformas.

Palabras clave: legislación sobre protección al empleo, costes de despido, desempleo.

Códigos JEL: J52, J53, K31, K41. 


\section{Introduction}

In most countries Employment Protection Legislation (EPL, henceforth) imposes that workers dismissals must have a "fair cause". ${ }^{1}$ Additionally, EPL typically distinguishes between economic redundancies and disciplinary layoffs, and imposes different legal procedures and severance payments depending on the cause of the dismissal. Even in those countries where EPL (or lack of it) follows the doctrine of "employment at will" (as it is the case, for instance, in the US), common-law restrictions that limit employers ability to fire are becoming more and more prevalent (see Autor et al., 2004).

Labor Courts' intervention in the resolution of dismissals introduces a significant wedge between "legal" firing costs (i.e., those established by EPL) and "effective" firing costs (i.e., those that employers actually have to cope with during and after Labor Courts' intervention). ${ }^{2}$ A part of this wedge is the cost arising from complex/time-consuming legal procedures; another part comes from the uncertainty about judges' rulings and the possibility that "fair" dismissals, from the employers' interpretation of EPL regulations, are finally ruled out as "unfair" by Labor Courts.

In principle, uncertainty on Labor Courts rulings could be reduced by EPL stipulating clearly the conditions under which redundancies and layoffs are justified. However, whether judges are neutral and unbiased agents with no discretion in their rulings over mandated legislation, and, hence, whether their rulings are based solely on laws and facts, are controversial issues. ${ }^{3}$ As for Labor Courts, there is wide empirical evidence showing that judges do seem to exploit some degree of discretion, and that, in some instances, they act under a kind of "social motivation". For instance, in Italy there is some association between local labor market conditions, such as the unemployment rate, and labor courts' decisions (Macis, 2001, Ichino et al., 2004); in Germany, even after controlling for the fact that court activity varies systematically with the political leaning of the government that appoints judges, there is a significant positive relation between labor court activity and unemployment (Berger and Neugart, 2011); and, in the UK unemployment and firms' bankruptcy rates seem also to be statistically associated to the probability of judges deciding in favor of dismissed employees in unfair dismissal trials (Marinescu, 2011).

In those countries where EPL is stricter, the gap between firing costs of fair

\footnotetext{
${ }^{1}$ All OECD countries, with the exception of the United States, require that dismissals should be justified in some way in addition to prohibiting discriminatory dismissals on a wide range of grounds. The ILO's Convention 158 on Termination of Employment, which Spain ratified in 1985, states that "The employment of a worker shall not be terminated unless there is a valid reason for such termination connected with the capacity or conduct of the worker or based on the operational requirements of the undertaking, establishment or service".

${ }^{2}$ OECD (2013), chapter 2, provides a descriptive analysis of how labor courts intervene in workers' dismissal cases in several countries. Within OECD coutries, Spain and Portugal, together with Turkey and Chile, are the countries in which dismissal cases are under the jurisdiction of only professional judges in Labor Courts.

${ }^{3}$ See Bornstein and Miller(2009), Posner (2010), Muñoz Aranguren (2011), and Danziger et al. (2011). In the Annex we give some information on the "potential social motivation" of Spanish judges acting in the labor jurisdiction.
} 
and unfair dismissals is larger, which makes Labor Courts' intervention more critical to the determination of "effective" firing costs. Moreover, the decisive role of Labor Courts at determining firing costs creates room for strategic behavior by employers and dismissed employees in the initiation and resolution of dismissals. Most EPL reforms aimed at reducing firing costs typically focus on decreasing firing costs and severance payments for "unfair" dismissals, which has some controversial normative implications, as it builds down to making less costly what is, from a social point of view, "unfair". An alternative reform strategy is to redefine the "fair causes" for dismissals, assuming that Labor Courts will change their rulings accordingly. Whether this assumption should be taken for granted is also controversial.

In this paper we analyze the impact of recent EPL reforms in Spain that widened the definition of "fair" causes for economic redundancies. Since data on individual cases are not available, we look at the proportion of fair dismissals as ruled by Labor Courts across Spanish provinces before-and-after the EPL reforms. We perform this comparison taking into account a set of co-variates (local labor market conditions, characteristics of the Labor Courts, pre-trial conciliations, congestion of Labor Courts) which may determine the selection of dismissal cases ruled by Labor Courts and, hence, alter their rulings for reasons other than the extension of fair causes of economic redundancies. Since our variable of interest (the proportion of fair dismissals as ruled by Labor Courts) shows a positive correlation with the local unemployment rate, we also look at the change in that correlation before-and-after the reform. Thus, our identification assumption relies on the control for observed heterogeneity in the composition of dismissal cases solved by Labor Courts across provinces, on the assumption that other effects of the reforms, besides the widening of the definition of economic redundancies, and changes in labor market conditions affected Labor Court rulings only through this set of co-variates. Thus, we regress the proportion of dismissals being ruled out as fair by Labor Court across provinces and across time on a time dummy variable and the set of co-variates described above. We read the effects of the extension of fair causes of economic redundancies on Labor Court rulings from the coefficients of the time dummy and its interaction with the local unemployment rate. Our interpretation of the results is that the extension of fair causes of economic redundancies only decreased the negative association between rulings declaring dismissals fair and the local unemployment rate.

The paper is organized in four more sections. First, we describe the particular features of Spanish EPL and its reforms in 2010 and 2012, with a specific focus in changes regarding the causes for dismissals (Section 2). Secondly, we lay off a theoretical model of firms' firing decisions under uncertainty of Labor Court rulings, to identify the main channels through which the widening of fair causes for economic dismissals could change the selection of dismissal cases brought to Labour Courts and its impact on "effective" firing costs of economic redundancies (Section 3). Our data analysis is presented in Section 4. Finally, Section 5 concludes. 


\section{EPL in Spain: "Fair" and "Unfair" Firings}

Before 2010 Spain was among the countries where EPL for regular workers was thought to be stricter. Spanish legislators, facing a perceived political infeasibility of reducing EPL under regular employment contracts, introduced employment flexibility at the margin by creating a wide array of "atypical" contracts, consolidating the dual nature of Spanish EPL. ${ }^{4}$ While regular employees are entitled the right to go to court to appeal the cause of the dismissal, and may get higher severance payments in case of unfair dismissals (see Figure 1 for a general outline of the layoff procedures), temporary employees cannot appeal the termination of their contracts. Thus, employers use fixed-term and other kind of temporary contracts (nowadays amounting to about $25 \%$ of employment) to buffer against negative shocks leading to downsizing of their labor force. ${ }^{5}$

In a nutshell and before the recent reforms, EPL for regular employees was based on the following principles:

- Dismissals were considered to be justified only in very restrictive cases, and only as a measure of "last resource". As for economic redundancies, they were considered "fair" only when there were negative economic situations for the company, or technical, organizational or production problems that put on compromise the viability of the company, and, moreover, no other measures could restore the economic viability of the firm. There were no specific provisions clarifying what "negative conditions" meant, so the ambiguity of the definition and the additional condition about the lack of other solutions, gave judges a great deal of discretion. As for disciplinary layoffs, the legislation referred to misconduct or lack of adaptation of the employee to the job's task as the main justified causes.

- The employer had the burden of proof that the firing was justified, both under economic and disciplinary causes.

- Judges must apply the interpretive principle "in dubio pro operario", according to which, in case of doubt they ought to rule in favor of the dismissed employee.

- As for severance payments, employees on permanent contracts who were dismissed for "fair" economic reasons were entitled to a severance pay of 20 days' wages per year of seniority, with a maximum of 12 months' wages. Employees dismissed for disciplinary reasons with a "fair" ruling were entitled to no severance pay and no interim wages.

- Dismissed employees could appeal to a labor court and, if the dismissal was ruled out to be "unfair", firms either had to pay 45 days' wages per year of seniority with a maximum of 42 months' wages or to reinstate the

\footnotetext{
${ }^{4}$ See Bentolila et al. (2012). There is and extensive literature documenting the negative effects of dualism in the Spanish labor market (among others, García-Serrano, 1998, Bentolila and Dolado 1994, Bentolila et al., 2008, and Wölfl and Mora-Sanguinetti, 2012).

${ }^{5}$ See Costain, Jimeno, and Thomas (2010).
} 
worker, regardless of the alleged cause. From 1996, there was a secondtier of permanent contracts targeted at some population groups, under which the severance pay in case of unfair dismissals was 33 days' wages per year of seniority with a maximum of 24 months' wages. Up to $2002^{6}$ in case of unfair dismissals the firm was also obliged to pay wages corresponding to the period between the date of the dismissal and the date of the court ruling. Starting in 2003 the payment corresponding to the interim wages could be waived if the firm accepted that the dismissal was unfair upon dismissal. From this date onwards, most firms accepted to pay the severance pay for unfair dismissal up-front, and avoid a Labor Court intervention that could impose the payment of interim wages.

- Moreover, Labor Courts could also declare the dismissal "null", if they appreciated "discrimination" (a violation of the fundamental rights of the employee) or breach of union rights as the real motivation for the dismissal. In this case, the dismissed employee ought to be reinstated and interim wages paid. However, these circumstances were rather infrequent. ${ }^{7}$

Since the legal procedures for disciplinary layoffs were simpler, and severance pay in case of unfair dismissal was the same than under economic redundancies, employers most frequently initiated dismissals alleging disciplinary causes. During the 1984-2010 period, about 70\% of dismissal cases resolved by Labor Courts' rulings were declared "unfair", with only a few of them being declared "null".

Since September 2010 there have been two significant EPL reforms in Spain, together with modifications of collective bargaining legislation, and some other measures addressed to reduce youth unemployment and increase the effectiveness of intermediation by public employment services. ${ }^{8}$ As for EPL, the most relevant legal changes were the following:

- The conditions under which a dismissal for economic reasons is considered to be fair were significantly extended, including the incidence of current or anticipated losses, and a persistent decline in the firm's level of revenues that could affect to its economic viability or its ability to maintain its level of employment.

- Moreover, the employer no longer has to provide an objective proof that dismissal was the only measure to restore the economic viability of the firm, but some evidence that the dismissal decision was needed to preserve the firm's current or future competitive position.

- The 2010 reform reversed the burden of proof, so that it is now on the employees when they claim that the dismissal was unfair.

\footnotetext{
${ }^{6}$ Law 45/2002 in effect since December 14, 2002.

${ }^{7}$ For further evidence, see Palomo Balda (2013).

${ }^{8}$ Labor Reform Law of 2010, the Royal Decree-Law of 2011 and the Labor Reform Law of 2012
} 
- The labor market reform of 2012 made further progress on the clarification of what "negative economic causes" meant. Thus, after this date a dismissal is to be considered "fair" if "the level of revenue or sales of the company was lower than in the same quarter of the previous year". Furthermore, interim wages in case of "unfair" dismissals were eliminated de facto, even if the employer opted for the reinstatement of the dismissed employee. That is, employers can now wait until the labor court ruling and, in case of a unfavorable one to their interests, the may reinstate dismissed employees without them receiving any severance pay nor interim wages.

As stated in the general outline (see Figure 1), both before and after the reforms a conciliation stage ("out-of-court conciliation") prior to the labor court ruling is compulsory. As shown below, a large number of conflicts are settled in this stage, affecting to the selection of cases solved by Labor Courts' rulings.

It is conceivable that the EPL reforms of 2010 and 2012 ought to increase the proportion of economic redundancies being ruled out as fair by the Labor Courts. It is also conceivable that the reforms lead to an increase in litigation, as employers may have now lower incentives to negotiate with dismissed employees, ${ }^{9}$ and to changes in the causes alleged by the employers, as the perceived relative cost of economic redundancies with respect to disciplinary layoffs may have significantly diminished. As for Labor Court activity, one would expect a slowdown, as judges get adapted and learn the new set of rules, so that congestion rates may have temporarily increased. Hence, besides the direct impact on labor court rulings, the reforms gave rise to other effects by which the selection of cases solved by Labor Courts may have changed and, thus, the proportion of dismissals being ruled out as fair could be different after the reforms for other reasons than the practical implementation of the new definition of "fair" economic redundancies. We try to clarify these channels by means of a theoretical model in the next section.

\section{The determinants of labor courts' rulings on firings: A theoretical model}

The model tries to resemble the most important features of EPL in Spain in order to identify the main channels through which recent EPL reforms may have altered Labor Court rulings on firings. Its main motivation is to help us to gauge to what extent our data analysis can be conclusive on the impact of the reforms on "effective" firing costs.

The main assumptions of the model are:

\footnotetext{
${ }^{9}$ We must note, however, that recognizing that the dismissal was "unfair" up-front is still a common strategy in Spain in order to avoid potentially long and uncertain trials.
} 
1. Employers decide to dismiss a worker and the reason on which to justify it. (S)he makes an offer to the dismissed employee to settle the case before going to the labor court. If the worker refuses the offer, the case goes to Labor Court and the judge settles the dispute.

2. There are two types of firings: those justified by economic reasons- $(r)$ and those in which disciplinary motives are alleged as the cause of the dismissal $(d)$.

3. Dismissals can have a good "cause" $(c)$ or not $(n c)$.

4. Judges may be "socially motivated" $(s)$-biased in favor of the dismissed employee- or "neutral" (ns). The proportion of "neutral" judges is given by $\alpha$.

5. In each case $\{r, d\}$ the labor court ruling can be "fair" $(f)$, "unfair" $(u)$, or "null" $(n)$.

6. Employers pay red tape costs which are higher for economic redundancies than for disciplinary layoffs $\left(\tau^{j}, j=\{r, d\}\right.$, with $\left.\tau^{r}>\tau^{d}\right)$ Dismissed employees do not pay any red tape costs.

7. Severance payments are:

-Redundancies: $c^{f}$ (if the case is ruled "fair") and $c^{u}$ (if ruled "unfair" or "null").

-Dismissals: 0 (if the case is ruled "fair") and $c^{u}$ (if ruled "unfair" or "null").

8. To accommodate settlements out of the Labor Court, employers $(e)$ and dismissed employees $(w)$ must have different subjective probabilities about the rulings.

The following Table gives the probabilities that the labor court rules in favour of the employer (redundancy/dismissal is "fair") for each possible case, assigned by both employers and dismissed employees $\left(p_{i}^{j}\right.$ where $\left.j=\{r, d\}, i=\{e, w\}\right)$.

Table 1. Probabilities of "fair" rulings, across causes and judges' type

\begin{tabular}{|cc|c|ccc|}
\cline { 3 - 6 } \multicolumn{1}{l|}{} & & $n s$ & \multicolumn{3}{c|}{$s$} \\
\hline$c$ & $r$ & $x_{i}^{r}$ & $x_{i}^{r} \widetilde{\delta}$ & $\widetilde{\delta}<1$ \\
& $d$ & $x_{i}^{d}$ & $x_{i}^{d} \widetilde{\delta}$ & $\widetilde{\delta}<1$ \\
\hline$n c$ & $r$ & $y_{i}^{r}$ & & 0 & \\
& $d$ & $y_{i}^{d} \approx y_{i}^{r}$ & & 0 & \\
\hline
\end{tabular}

We obviously assume that the probability of a dismissal to be ruled out as "fair" is higher when there is a "good" cause $\left(x_{i}^{j}>y_{i}^{j}\right.$, for all $\left.i, j\right)$. To simplify the notation, and without any relevant loss of generality, we also assume that 
"socially motivated" judges have the same "bias" for economic redundancies as for disciplinary layoffs, and that, under no cause, they always rule a dismissal "unfair". Since $\alpha$ is the proportion of "neutral" judges, then

$$
p_{i}^{j}(f \mid c)=\delta x_{i}^{j} \text {, where } \delta=\alpha+(1-\alpha) \widetilde{\delta}<1 \text {, and } p_{i}^{j}(f \mid n c)=\alpha y_{i}^{j} \text { for } j=r, d .
$$

The following table give what the Firms Expects to Pay $(F E P)$ and what the Worker Expects to Get $(W E G)$ if the case is settled by a Labor Court ruling.

Table 2. Expected Payoffs if dismissals settled at labor court

\begin{tabular}{|c|c|c|c|}
\hline & & $F E P$ & $W E G$ \\
\hline$c$ & $\begin{array}{l}r \\
d\end{array}$ & $\begin{array}{c}\delta x_{e}^{r} c^{f}+\left(1-\delta x_{e}^{r}\right) c^{u}+\tau^{r} \\
\left(1-\delta x_{e}^{d}\right) c^{u}+\tau^{d}\end{array}$ & $\begin{array}{c}\delta x_{w}^{r} c^{f}+\left(1-\delta x_{w}^{r}\right) c^{u} \\
\left(1-\delta x_{w}^{d}\right) c^{u}\end{array}$ \\
\hline$n c$ & $\begin{array}{l}r \\
d\end{array}$ & $\begin{array}{c}\alpha y_{e}^{r} c^{f}+\left(1-\alpha y_{e}^{r}\right) c^{u}+\tau^{r} \\
\left(1-\alpha y_{e}^{d}\right) c^{u}+\tau^{d}\end{array}$ & $\begin{array}{c}\alpha y_{w}^{r} c^{f}+\left(1-\alpha y_{w}^{r}\right) c^{u} \\
\left(1-\alpha y_{w}^{d}\right) c^{u}\end{array}$ \\
\hline
\end{tabular}

The employer has the option to claim, as the cause of firings, either redundancy or disciplinary reasons, regardless of the true cause (or the lack of it). Thus,

- Economic redundancies with cause are initiated alleging economic reasons if and only if $\delta x_{e}^{r}\left(c^{u}-c^{f}\right)-\alpha y_{e}^{d} c^{u}>\tau^{r}-\tau^{d}$. If that condition is not satisfied they are disguised as disciplinary layoffs.

- Economic redundancies without cause are always initiated alleging disciplinary reasons since $\alpha y_{e}^{r}\left(c^{u}-c^{f}\right)-\alpha y_{e}^{d} c^{u}<\tau^{r}-\tau^{d}$ (under the assumption that $y_{e}^{r} \approx y_{e}^{d}$ ).

- Disciplinary layoffs with cause are always initiated alleging disciplinary reasons since $\alpha y_{e}^{r}\left(c^{u}-c^{f}\right)-\delta x_{e}^{d} c^{u}<0<\tau^{r}-\tau^{d}$ (since $y_{e}^{r}<x_{e}^{d}$ ).

- Disciplinary layoffs without cause are always initiated alleging disciplinary reasons since $\alpha y_{e}^{r}\left(c^{u}-c^{f}\right)-\alpha y_{e}^{d} c^{u}<0<\tau^{r}-\tau^{d}$ (under the assumption that $y_{e}^{r} \approx y_{e}^{d}$ ).

Since there is the possibility of a private settlement, not all dismissals go to court, but only those for which $F E P<W E G$.

- Economic redundancies with cause go to labor court whenever:

$$
\delta\left(x_{e}^{r}-x_{w}^{r}\right)\left(c^{u}-c^{f}\right)>\tau^{r}
$$

Hence, the smaller the bias $(1 / \delta)$ from "socially-motivated" judges is, and the larger the differences $c^{u}-c^{f}$ and $x_{e}^{r}-x_{w}^{r}$ are, the higher the likelihood of economic redundancies going to court is. 
- Similarly, disciplinary dismissals with cause go to labor court whenever:

$$
\delta\left(x_{e}^{d}-x_{w}^{d}\right) c^{u}>\tau^{d}
$$

- Dismissals without a cause (always initiated alleging disciplinary reasons) go to court whenever:

$$
\left(y_{e}^{d}-y_{w}^{d}\right) c^{u}>\tau^{d}
$$

Finally, we assume that employers and workers' subjective probabilities on rulings are centered around the true probabilities $\left(x^{j}=\frac{x_{e}^{j}+x_{w}^{j}}{2}, y^{j}=\frac{y_{e}^{j}+y_{w}^{j}}{2}\right.$, $j=\{r, d\}$.

In our data, we observe:

$$
p(f)=\delta\left(\beta^{r} x^{r}+\beta^{d} x^{d}\right)+\alpha\left(1-\beta^{r}-\beta^{d}\right) y^{d}
$$

where $\beta^{r}$ and $\beta^{d}$ are, respectively, the weights of economic redundancies and disciplinary layoffs with cause going to labor court (which are determined by the incidence of each type of firings and the conditions about out-of-court settlements above). However, what we would like to know is the impact of the reforms on $p^{r}(f \mid c, n s)=x^{r}$ and, plausibly, on the bias on rulings of economic redundancies due to "socially motivated" judges $(1 / \delta)$.

As the previous equation makes it clear, there are several channels through which a EPL reform may change the observed frequency of fair firings in Labor Courts rulings:

- Changes in the proportion of "socially motivated" judges or in the bias introduced by them in court rulings $(\alpha$ and $1 / \delta)$.

- Changes in the weights of economic redundancies and disciplinary dismissals being settled at courts.

- Changes in the likelihood of an economic redundancy (with cause) be declared as "fair" $\left(x^{r}\right)$.

- Changes in the likelihood of a disciplinary layoff (with cause) be declared as "fair" $\left(x^{d}\right)$.

As for differences in $p(f)$ across provinces, they can be due to:

- Different proportion of "neutral" judges $(\alpha)$. We disregard differences in $\{x, y, \widetilde{\delta}\}$, since we cannot think of reasons why these parameters may differ across provinces other than the judge's type.

- Different weight of economic redundancies due to the different incidence of "economic reasons" $\left(\beta^{r}\right)$. 
- As for the incidence of disciplinary layoffs $\left(\beta^{d}\right)$, we assume that they are equal across provinces (after conditioning for unemployment and the sectoral composition of employment), as we have no reasons to expect employees to have differences in misconduct or adaptation to jobs' tasks across provinces, once that local labor market conditions and the sectoral composition of firms effects are accounted for.

Thus, this model highlights the most important selection effect is the changing distribution of economic redundancies with good causes, disciplinary layoffs with good causes, and economic redundancies disguised as disciplinary layoffs. It is conceivable that EPL in 2010 and 2012 increased the first type of firings. Moreover, during the crisis unemployment increased very much, so that it is also conceivable that the incidence of disciplinary layoffs with a good cause has fallen ("fear-of-unemployment effect"). Finally, the incidence of economic redundancies disguised as disciplinary layoffs ought to have decreased too, since lower red tape costs for economic redundancies give employers less incentives to disguise them as disciplinary layoffs. But these conjectures assumed that the incidence of conciliation settlements is unchanged, which may not be the case if subjective probabilities of employers and employees have changed differently during the unemployment crisis and after the reforms. By specifying the relationship between our variable of interest (the probability that a economic redundancy is declared fair by the Labor Courts, $x_{i}^{r}$ ) and the variable that we can measure (the proportion of dismissal cases being declared fair by the Labor Court, $p(f)$ ), the model suggests the set of co-variates to control for selection effects, namely those related to the composition of dismissal by cause and to some characteristics of the Labor Courts.

Under certain conditions, the model also yields some bounds on the effects of EPL reforms on $p_{i}^{r}(f \mid c, n s)=x_{i}^{r}$, whose increase was one of the main objective of the reforms. For instance, let us assume that the proportion of "neutral" judges and the bias of "socially motivated" judges do not change as a result of EPL reforms ( $\alpha$ and $\delta$ remain unchanged). Let us also assume that EPL reforms did not introduce any significant change in judges, employers, and employees perceptions of disciplinary dismissals (so that $x^{d}$ and $y^{d}$ also remain unchanged). Then,

$$
d p(f)=\delta \beta^{r} d x^{r}+\left(\delta x^{r}-\alpha y^{d}\right)\left(d \beta^{r}+d \beta^{d}\right)+\delta\left(x^{d}-x^{r}\right) d \beta^{d}
$$

Given that $\delta>\alpha, x^{r}>y^{d}$, that $d \beta^{r}+d \beta^{d}>0$, (the incentives to disguise redundancies as disciplinary layoffs diminish after an EPL reform that widens the definition of fair redundancies) $d \beta^{d}<0$ (there are less disciplinary layoffs with cause in recessions) and, assuming that $x^{r}>x^{d}$, it follows that

$$
d x^{r}<\frac{1}{\delta \beta^{r}} d p(f)
$$

Hence, since $\delta>\alpha$ (which according to the information in the annex is around 0.5 ) and assuming $\beta^{r}$ is also around 0.4 (according to the aggregate 
information on reasons for entry into the unemployment benefit system), the wedge between $d x^{r}$ and $d p(f)$ is at most a factor of 5 .

\section{Empirical strategy}

\subsection{Data}

We use data on Labor Courts rulings at the provincial level (50, excluding Ceuta and Melilla for which no specific judicial information is available) and the period 2004Q1-2014Q3. These data were provided by the Spanish General Council of the Judiciary (Consejo General del Poder Judicial, henceforth CGPJ) and contain information on the total number of conflicts resolved by Labor Courts and on the sign of the ruling, i.e. if they were resolved in favour of the plaintiff (the employee) or the defendant (the employer). The data considered in our analysis belong exclusively to the first instance of the labor jurisdiction and refer to individual dismissals. Some other clarifications regarding the use of judicial data follow:

- The Spanish jurisdiction dealing with the labor disputes is the labor ("social") jurisdiction (Orden de lo Social). Labor relations in Spain are regulated by the labor legislation, whose main piece is the Workers' Statute. Conflicts between employees and employers are resolved in the labor courts (Juzgados de lo Social) which are regulated by the Labor Procedure Act (Ley de Procedimiento Laboral) and, more generally, by the Organic Law of the Judiciary (Ley Orgánica del Poder Judicial). The latter sets out that labor related matters are exclusively assigned to the Labor Courts, so that the labor jurisdiction is separated from other jurisdictions (civil, criminal or administrative). This is one of the main differences with other countries, as for example, Italy, where a civil judge may also resolve a labor dispute. Spanish CGPJ data on Labor Courts thus differs from similar databases of other countries because it distinguishes the jurisdictions.

- The Spanish judicial system is composed of several hierarchical levels but it is considered a "one instance" one whereas appeals after the first instance are considered "extraordinary". Figure 1 shows how the legal case may proceed after an employee disagrees with the dismissal and decides to go to court. That is, the employee will claim against the employer before the first-instance labor court located in the town where she is employed. Once the judge has ruled the case, one of the parties (the employee or the employer) may appeal the first-instance judge's decision in the labor chamber of the High Court of Justice of the corresponding Spanish region. Finally, the latter decision of the High Court of Justice may be contested at a national level at the labor Chamber of the Audiencia Nacional or, before, the Fourth Chamber of the Supreme Court. As it was said, those appeals are only possible in "extraordinary cases" ("suplicación" and "casación") 
and are solved after long periods of time (typically, around 3 years). Thus, by restricting our analysis to the first-instance labor court rulings we are not excluding a significant part of the information.

As the main variable for our analysis we compute the proportion of Labor Court rulings declaring dismissals fair for each province and quarter in the sample. We can also observe the presence of the different types of judges serving in the Spanish judicial system (i.e. if the judge was holding office in the court when solving the complaint against the specific dismissal, or, on the contrary, if the judge was appointed temporarily as reserve or substitute for an absent member of the bench or, finally if he was holding office in another court and was temporarily appointed to serve in the court for solving the specific dismissal). ${ }^{10}$ Using this information we construct two control variables: the proportion of Labor Court rulings issued by a judge that was holding office in the court, and a rate of temporary posts in the courts (that is the sum of days, per quarter, in which the acting judge was absent, either substituted or not by a temporary judge).

Since EPL reforms are likely to increase the time needed (at least in the short term) for Labor Courts to solve dismissal disputes, as judges may need to become accustomed to the new set of rules, we also compute a measure of the "congestion" of the judicial system, when solving dismissal conflicts. Following García-Posada and Mora-Sanguinetti (2014) the congestion rate is defined as the ratio between the sum of pending cases (measured at the beginning of the quarter) plus new cases in a specific quarter to the cases resolved in the same quarter, that is

congestion_rate $(\text { dismissals })_{i, t}=\frac{\text { Pending_dismissals }_{i, t-1}+\text { New_dismissals }_{i, t}}{\text { Dismissals_resolved }_{i, t}}$

In a congested system, like the Spanish one, the ratio is usually above 1 . We have also constructed a measure which captures the "general" workload of the Spanish labor jurisdiction called "out-of-court conciliations ratio". It is calculated as the ratio of the number of out-of-court conciliations finished with agreement divided by the sum of those conciliations (with agreement) and the total number of dismissal lawsuits. Among other effects, we would like to observe the effects of EPL reforms on the success of those conciliations to reduce the workload of the judicial system. With the disappearance of the "interim wages" (if the dismissal was finally declared "unfair") the incentive of the parties to agree at the out-of-court court conciliation may have changed.

Other control variables to be included in the empirical analysis refer to the economic environment of each province. In particular, it seems important to

\footnotetext{
${ }^{10}$ While judges holding office in a court are judges who have passed a public exam and belong permanently to the judiciary, judges appointed temporarily do not belong to the Judicial power (they are lawyers or jurists who are appointed temporarily by the CGPJ during a period of a year). See Martín-Román et al. (2013) for further evidence on the effects implied by the different types of judges in the system.
} 
control for the local unemployment rate (in deviations with respect to the sample mean), sectoral composition (relative weights of agriculture, industry, construction and services sectors), and the temporary employment rate (proportion of employees under fixed-term contracts out of the total number of employees), since these three variables could be related to the incidence of economic dismissals relative to disciplinary layoffs. ${ }^{11}$ Finally, as for the impact of the EPL reforms, we define the following two variables:

$$
\begin{aligned}
& \text { reform } 1=\left\{\begin{array}{l}
0, \text { if } t \leq 2010 Q 2 \\
1, \text { if } t>2010 Q 2
\end{array}\right\} \\
& \text { reform } 2=\left\{\begin{array}{l}
0, \text { if } t \leq 2012 Q 1 \\
1, \text { if } t>2012 Q 1
\end{array}\right\}
\end{aligned}
$$

and, in some specifications, we interact these two variables and the unemployment rate at each province (interaction 1 and interaction 2 ) to measure to what extent EPL reforms have also generated some changes in the statistical association between Labor Court rulings and unemployment.

Table 1 displays some descriptive statistics of the proportion of Labor Court rulings that declare dismissals fair at the national level by year, while Table 2 (and Figure 2) provides the same statistics at the provincial level for the whole period of analysis. At the aggregate level, around $27.5 \%$ of cases are declared fair, although there are significant differences across time and provinces. In the mid-2000s the proportion of dismissal cases ruled as fair by Labour Courts was around 30\%, to start decreasing in 2008 and reached $25 \%$ in 2010, the year of the first change in the legal definition of "fair" economic redundancies; then, it increased temporarily in 2011 to $27.5 \%$ to decrease again below $24 \%$ in 2013 and 2014. As for provinces, there are also substantial variation: Álava, Burgos, Palencia or Teruel seem to have a higher proportion of dismissals being declared fair (more than 33\%), while in Ávila, Alicante, Toledo, and Tenerife this proportion is less than $20 \%$.

\subsection{Results}

We start by measuring differences-in-differences of the proportion of Labor Court rulings that declare dismissals "fair" using the following specification:

$$
\text { Court_rulings } s_{i t}=\alpha_{i}+\beta \text { reform } 1_{i t}+\sum_{k=1}^{K} \delta_{k} \text { Control }_{i t}^{k}+\varepsilon_{i t}
$$

where the subindexes $i$ and $t$ refer, respectively, to province $(i: 1 \ldots 50)$ and time period $(t: 2004 Q 1-2014 Q 3), \alpha_{i}$ are province fixed effects, reform1 (alternatively, reform2) represents the labor market reform as explained in the previous section and control $_{i t}$ is a set of control variables. We estimate both a linear

\footnotetext{
${ }^{11}$ For computing these variables, we use data from the Spanish Labor Force Survey.
} 
specification and odds-ratios [Bishop et al. (1975), Williamson et al. (1995)]. ${ }^{12}$ These specifications are estimated by a within-group estimator. Clustered standard errors robust to heteroskedasticity and serial correlation are provided into parentheses. ${ }^{13}$ We also report standard errors using bootstrapping techniques (Efron, 1979), which are very similar to those computed under clustering.

Choosing the province as a unit of study would lead to misguiding results in the case that dismissals initiated in a particular province were settled by Labor Courts at another province. However, Spanish labor law strongly limits the labor court where to settle the firing dispute to one of the province where the employment services were provided, i.e., where the company is located, or of the province where the employee has its main residence. ${ }^{14}$ Spanish provinces are large enough so that in almost all the cases both places (company headquarters and residence of the worker) are in the same province. ${ }^{15}$ As a summary, Table 3 provides the definition and data sources for all the variables used in our empirical analysis and Table 4 displays their descriptive statistics.

Tables 5 to 12 report the estimation results. In each Table we present the results of eight different specifications, including alternative set of co-variates (the rate of temporary contracts, the sectoral composition of GDP in the province, a group of controls for the characteristics of Labor Courts side, the congestion rate when solving dismissal conflicts, and a control for the congestion of the judicial system when solving specifically pre-trial conciliations). Finally, as an alternative robustness check, we estimate the specification with all co-variates, excluding observations from Madrid and Barcelona. ${ }^{16}$

Overall, our reading of the results boils down to two main messages. First, after taking into account that there is a negative statistical association between the local unemployment rate and the proportion of dismissal cases being ruled as "fair" by Labor Courts, the EPL reforms, specially the one taking place in 2010, are associated with an increase of that proportion of about 2.5 percentage points; while the effect of the 2012 EPL reform, not always statistically significant, seems to have been smaller, about 1.5 additional percentage points. ${ }^{17}$ Secondly,

${ }^{12}$ This latter transformation is based on the following expression for the dependent variable:

$$
\frac{\text { Court_rulings }}{\text { it }}
$$

\footnotetext{
${ }^{13}$ Clustering by provinces take into account the fact that our provincial data come from the aggregation of the individual Labor Courts existing in each province, whose number varies with the size of the province. It also takes into account the possibility of different serial correlation across provinces. As for the minimum number of clusters required, see Angrist and Pischke (2009).

${ }^{14}$ Article 10 of the Labor Procedure Act (Ley de Procedimiento Laboral)

${ }^{15}$ According to the Labor Force Survey, workers commuting to a province other than their province of residence amount to $4.6 \%$ during the period 2005-2013.

${ }^{16}$ Madrid and Barcelona are the most populated and economically active provinces of Spain. Madrid holds the headquarters of the main instance labor tribunals. Both cities hold the headquarters of the main Spanish (and continental) Law firms (Mora-Sanguinetti and Garoupa, 2015).

${ }^{17}$ Notice, however, we have fewer observations to estimate the impact of the 2012 reform. Introducing both reform dummies in the same regression do not qualitatively change the results.
} 
the increase in the proportion of dismissal cases being declared as "fair" by Labor Courts mostly arises from a less negative relationship between that rate and local unemployment. In other words, given that local unemployment rates were increasing after 2010, without the EPL reforms the proportion of the dismissal cases being declared as "fair" would have been much lower.

As already explained, the changes in the probabilities of "fair" dismissals observed in our data sets cannot be interpreted as the subsequent effect of the widening of the legal definition of "fair" economic redundancies, since, among other things, the selection of dismissal cases solved by Labor Courts may have changed. For instance, if after the reforms employers were disguising more economic redundancies as disciplinary layoffs and more of these dismissal cases without cause are being solved by Labor Courts, the proportion of rulings declaring dismissals "fair" could decrease even if the widening in the legal definition of fair economic redundancies were being applied by the Labor Courts. Nevertheless, there are two pieces of evidence suggesting that this adverse selection of cases did not occur. The first one is that, at the national level, the proportion of entrants into the unemployment insurance system after a objective dismissal solved by a Labor Court has increased from less than 10\% in 2007 to around $40 \%$ in $2014 .^{18}$ Secondly, out-of-court conciliations have also increased after the reforms.

The change in the frequency of out-of-court conciliations after the reform can be seen in Tables 13 to 16 . Using data from the register of the administrative office in charge of supervising these conciliations, we can compute the ratio of dismissals solved by conciliation out of dismissals solved either by conciliation and Labor Court rulings by year and province. Regressing this ratio on the same sets of variables used in the regressions for fair dismissals rulings, we obtained that the ratio increased after the 2010 reform and, also, after the 2012 reform. As in the case of fair rulings, this ratio displays some negative statistics association with the local unemployment rate and, also, the main reason of its rise after the reform is a higher response to unemployment after the reforms. To what extent this is the results of employers and dismissed employees' expectation on Labor Court rulings becoming more similar after the reforms needs to be investigated with finer data. However, what this result indicates is that the selection of dismissal cases being solved by Labor Courts after the reforms, if anything, tilted towards more uncertain cases, probably those justified on economic reasons since these were the most affected by the reforms and, therefore, those for which employers and employees had less information on how Labor Courts rulings were going to be affected by the change in legislation.

As an indication that the change of legislation may have introduced more uncertainty on Labor Court rulings on economic redundancies is that the congestion of Labor Courts, as far as dismissals cases is concerned, also increased

\footnotetext{
${ }^{18}$ The composition of dismissals by economic redundancies and disciplinary layoffs at each province can be obtained from the administrative data on entries into unemployment. Unfortunately, we have been unable to get the Public Employment Office to grant us access to those data.
} 
after the reform (Tables 17 to 20) Again, we follow the same empirical strategy as with rulings and conciliations and regress the congestion rate by quarter and province on the same sets of variables used before. As it may be expected, and as usual after any legislative reform, Labor Courts show an increased congestion rate as a result of the arrival of the new legislation. In this case, the reform of 2010 would have increased the congestion rate by $0.3-0.6$ points on average, while the 2012 reform would have increased the congestion rate by 0.7 points. In this case, there are no statistically significant associations with the local unemployment rate driving the changes. ${ }^{19}$

\section{Conclusions}

When the gap between firing costs of "fair" and "unfair" dismissals is large, Labor Courts rulings on dismissal cases are critical for the determination of "effective" firing costs. According to the literature, labor judges often behave as socially motivated agents. Moreover, EPL creates several areas for strategic behavior by employers and dismissed employees in the justification and resolution of disputes, such as the choice of the alleged dismissal cause by the employer and agreements on out-of court and pre-trial conciliations. All these elements make it difficult to infer how EPL reforms may affect to the probability of economic redundancies being declared fair by Labor Courts. In this paper, we provide a theoretical model, tailored to the Spanish situation, to highlight several channels by which changes in EPL legislation may be translated into changes in effective firing costs and investigate the impact of two recent EPL reforms widening and making it more precise the definition of economic redundancies.

Using data on labor court rulings at Spanish provinces, and performing difference-in-difference estimation of the probability of a dismissal being declared fair, we find that after the 2010 EPL reform there has been an increase of about 2.5 percentage points in that probability. We have also provided some scattered evidence showing that, if anything, the selection of dismissal cases being solved by Labor Courts titled towards a higher weight of economic redundancies. Hence, even taking into account that there is a gap between the observed frequency of fair dismissal rulings by Labour Courts and the probability that an economic redundancy is declared "fair" we conclude that the strategy of the Spanish EPL reforms of 2010 and 2012, focused on changing the legal definition of fair economic redundancies, has not fully delivered a substantial reduction of "effective" firing costs. This conclusion has three implications for the policy debate on the need of introducing further labor market reforms. One is that the reduction in non-wage labor cost implied by the extension of the definition of economic redundancy has been minimal. Secondly and similarly, the change of the indicators about the stringency of EPL for regular contracts usually discussed in the debate (for instance the OECD indicators), insofar as they are based on changes in legal firing costs and neglect the costs from Labor

\footnotetext{
${ }^{19} \mathrm{On}$ the determinants of Labor Courts congestion and judges productivity, see Coviello, Ichino, and Persico (2014, 2015).
} 
Courts' intervention, overestimate the impact of the EPL reforms. Finally, since the reduction of effective firing costs for economic redundancies under the regular employment contract has been minor, and given that the difference between these firing costs and the termination costs of temporary contracts determines the proportion of employees with fixed-term contracts, the high incidence of temporary employment observed in Spain would not be very much reduced by these reforms.

\section{Annex: Some information on the ideological orientation of judges acting in the labor juris- diction}

Regarding the characteristics of the judges, the theoretical model distinguishes between judges that are "socially motivated" -biased in favor of the worker- $(s)$ or "neutral" (ns), being the former prone to interpreting EPL more favorably to dismissed employees. The relative weight of these two categories of judges is difficult to measure empirically. Some approximation can be obtained by the incidence of judges associations. While Spanish law prohibits a judge to join a political party or a labor union while she is on active duty, it allows association in professional groups, which happen to have some "ideological" orientations. Currently, the major associations in Spain are the "Asociación Profesional de la Magistratura" (APM), "Jueces para la Democracia" (JpD), "Asociación Francisco de Vitoria" (FV), "Foro Judicial Independiente" (FJI), and the "Asociación Nacional de Jueces" (ANJ). APM is perceived as conservative. JpD is considered progressive and FV and FJI are considered "moderate". ${ }^{20}$

Unfortunately, information on the presence of the judicial associations at the provincial level is not available. In this regard, we can only observe the relative weight of judges of different judicial associations at the fourth chamber of the Supreme Court (that is, the Chamber that settles employment and social security conflicts). This may be representative of the "ideological" orientation of first-instance labor courts for two reasons. First, the presence of the various associations in the Supreme Court may be the direct consequence of the presence of those associations at lower levels. Secondly, Supreme Court's decisions (jurisprudence) are compulsorily followed by judges at lower levels for interpretation of the Law, so that the survival of lower court decisions depends partially on their consistency with the Supreme Court decisions. As shown in Figure 3 , the relative weight of magistrates pertaining to progressive associations has gradually increased at the expense of conservative and moderate associations during last years. It is conceivable that this trend is associated with an increase in the propensity to rule dismissal cases in a pro-employee fashion. In terms of the theoretical model in the text, this corresponds to a decrease in the proportion of "neutral" judges $(\alpha)$, and, hence, to a downward bias in our estimation of the EPL reforms on the probability of a economic dismissal with "good" cause to be ruled as fair.

\footnotetext{
${ }^{20}$ No presence of FJI was found in the Fourth Chamber of the Supreme Court in our period of analysis.
} 


\section{References}

[1] Autor, D., Acemoglu, D. and D. Lyle (2004). "Women War and Wages: The Impact of Female Labor Supply on the Wage Structure at Mid-Century." Journal of Political Economy, 112(3), 497-551.

[2] Angrist, J. D. and J-S. Pischke, Mostly Harmless Econometrics: An Empiricist's Companion. Princeton University Press. Princeton (2009).

[3] Bentolila S. and J.J. Dolado (1994). "Labour Flexibility and Wages: Lessons from Spain", Economic Policy 9 (18), Centre for Economic Policy Research and Center for Economic Studies, Blackwell Publishing.

[4] Bentolila S., J.J. Dolado and J.F. Jimeno (2008). "Two-Tier Employment Protection Reforms: The Spanish Experience", CESifo DICE Report, Vol. 6, No. 4, CESifo Group, Munich.

[5] Bentolila, S., J.J. Dolado and J.F. Jimeno (2012). "Reforming an InsiderOutsider Labor Market: The Spanish Experience" IZA Journal of European Labor Studies 1.

[6] Berger, H. and M. Neugart (2011). "Labor courts, nomination bias, and unemployment in Germany", European Journal of Political Economy, 27, 659-673.

[7] Bishop, Y. M. M., Fienberg, S. E., and Holland, P. W. (1975). "Discrete multivariate analysis: Theory and practice". MIT Press, Cambridge.

[8] Bornstein, B. H. and M. K. Miller (2009). "Does a Judge's Religion Influence Decision Making?". Court Review: The Journal of the American Judges Association, 45, 112-115.

[9] Costain, J., J.F. Jimeno, and C. Thomas (2010): "Employment fluctuations in a dual labor market", Bank of Spain working paper 1013.

[10] Coviello, A. Ichino, and N. Persico (2014): "Time Allocation and Task Juggling", American Economic Review, Vol. 104, 2, 609-623.

[11] Coviello, A. Ichino, and N. Persico (2015): "The inefficiency of worker time use", Journal of the European Economic Association, (forthcoming).

[12] Danziger, S., Levav, J. and L. Avnaim-Pesso (2011). "Extraneous factors in judicial decisions", Proceedings of the National Academy of Sciences of the US, vol. 108 no. 17.

[13] Efron, B. (1979). "Bootstrap methods: Another look at the jacknife", The Annals of Statistics, 7(1), 1-26. 
[14] García-Posada, M. and J. S. Mora-Sanguinetti (2014). "Does (average) size matter? Court enforcement, business demography and firm growth". Small Business Economics Journal (forthcoming). DOI: 10.1007/s11187-014-9615$\mathrm{z}$.

[15] García-Serrano C. (1998). "Worker Turnover and Job Reallocation: The Role of Fixed-Term Contracts", Oxford Economic Papers, Vol. 50, No. 4, Oxford University Press.

[16] Ichino, A., Polo, M. and E. Rettore (2004). "Are Judges Biased by Labor Market Conditions?". European Economic Review 47(5), pp. 913-944.

[17] Macis, M. (2001). "Il mercato del lavoro e la giurisprudenza in materia di licenziamenti (Italia, 1989-1998)", Diritto delle Relazioni Industriali, 2.

[18] Marinescu, I. (2011). "Are Judges Sensitive to Economic Conditions? Evidence form UK Employment Tribunals", Industrial and Labor Relations Review, 64(4), 673-698.

[19] Martín-Román, A., Moral de Blas, A. and M. Martínez Matute (2013). "Tipo de juez y estimación de los casos de despido: un análisis de los Juzgados de lo Social en España", Cuadernos de Economía, vol. 36, 142154 .

[20] Mora-Sanguinetti, J. S. and N. Garoupa (2015). "Litigation in Spain, 20012010: Exploration of the market for legal services",.Banco de España Working Paper 1505.

[21] Muñoz Aranguren, A. (2011). "La influencia de los sesgos cognitivos en las decisiones jurisdiccionales: el factor humano. Una aproximación". InDret 2/2011 1-39.

[22] OECD (2013). "Employment Outlook". OECD Publishing. Paris.

[23] Palomo Balda, E. (2013). "111 sentencias en materia de despido colectivo (y 2 más): un balance provisional", Diario La Ley, 8136.

[24] Posner, R. A. (2010). "How Judges Think". Harvard University Press. Cambridge, Massachusetts.

[25] Williamson, J. M., Kim, K., and Lipsitz, S. R. (1995). "Analyzing bivariate ordinal data using a global odds ratio". Journal of the American Statistical Association 90, 1432-1437.

[26] Wölfl, A. and J. S. Mora-Sanguinetti (2012). "Improving the functioning of the Spanish labour market - Why the 2010 and 2011 reforms were not yet sufficient". Moneda y Crédito 234, 129-161. 
Figure 1: Layoff procedure in the Spanish labor jurisdiction

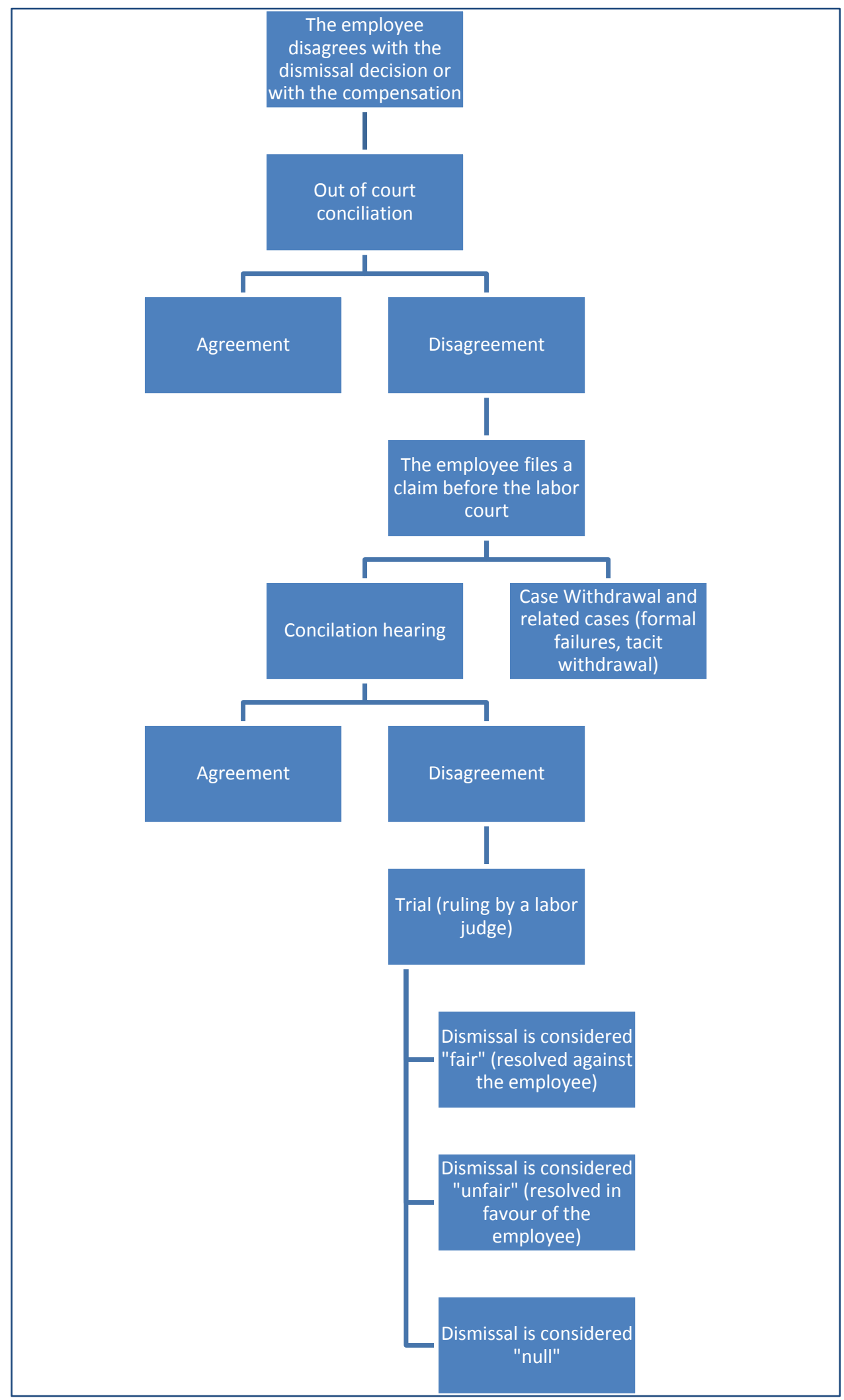

Source: Authors' own elaboration 
Figure 2: Average (2004-2014) percentage of labor court judgments ruling that the dismissal was fair

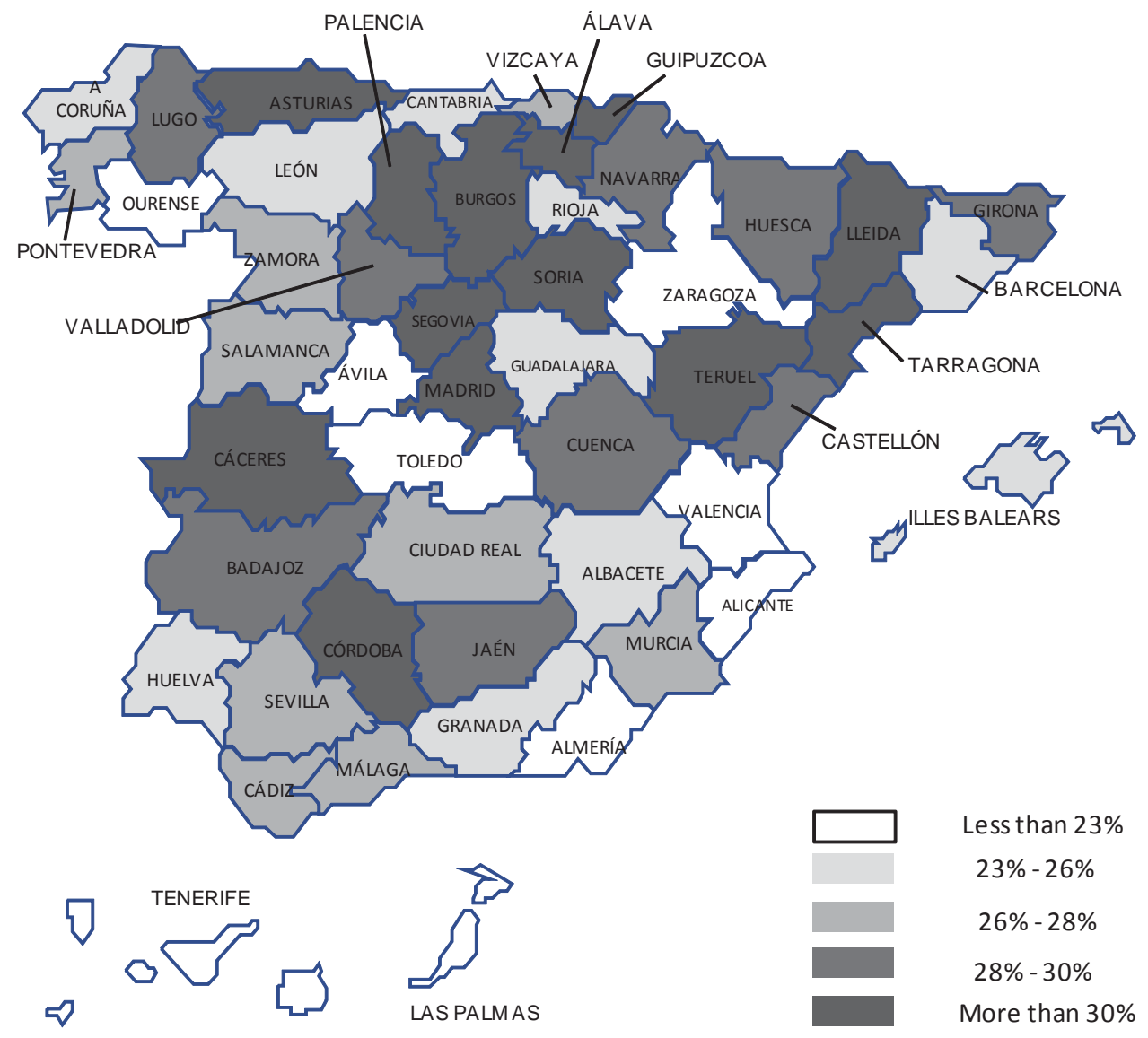

SOURCE: Authors' own elaboration 
Figure 3: Memberships by association in the Supreme Court (fourth chamber)

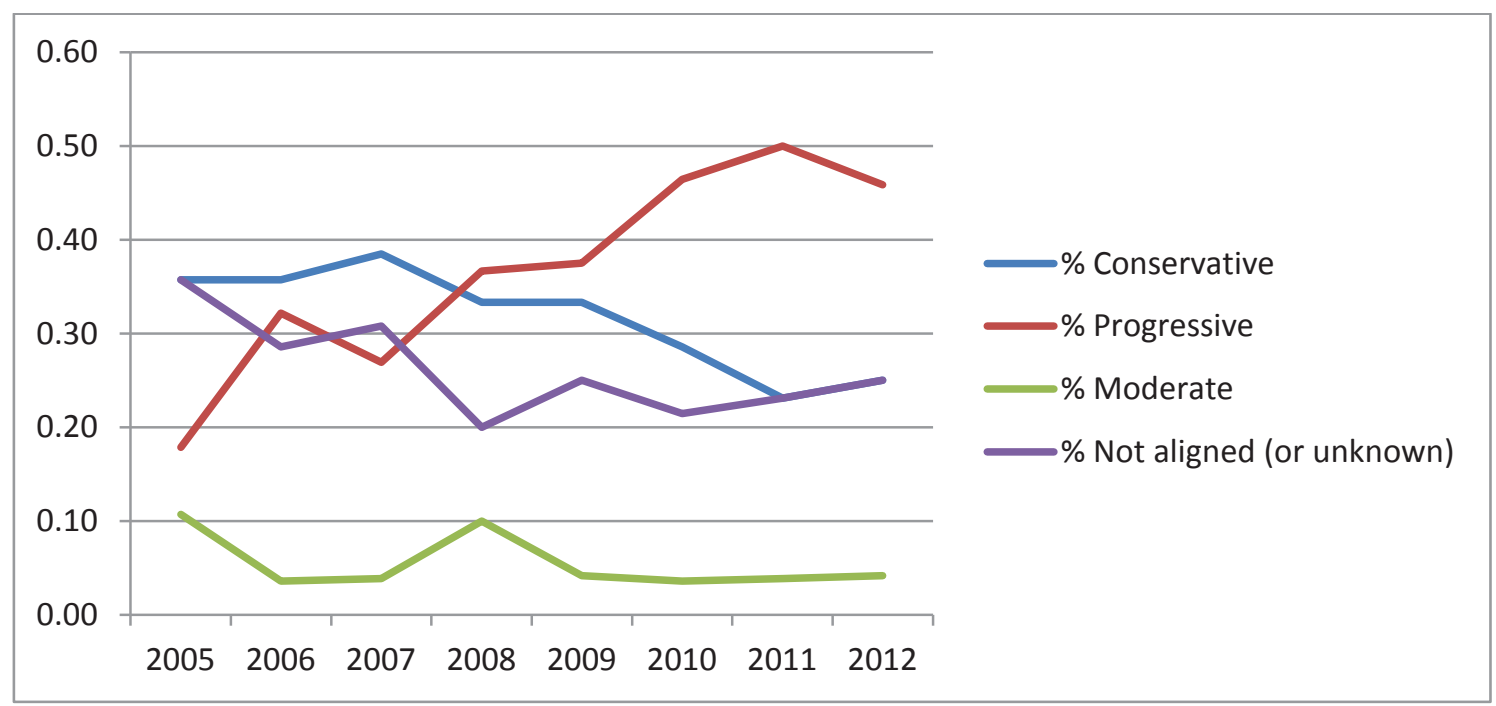

SOURCE: Authors' own elaboration using Memorias del Tribunal Supremo (2005-2012) 
Table 1: Summary statistics of the percentage of labor court judgments ruling that the dismissal was fair

\begin{tabular}{cccccc}
\hline Year & Observations & Mean & Std. Dev. & Min & Max \\
\hline 2004 & 200 & 0.2991 & 0.1102 & 0.0408 & 0.6667 \\
2005 & 200 & 0.3016 & 0.1096 & 0.0000 & 0.6923 \\
2006 & 200 & 0.3040 & 0.1026 & 0.0000 & 0.8333 \\
2007 & 200 & 0.2947 & 0.1058 & 0.0000 & 0.8000 \\
2008 & 200 & 0.2569 & 0.1009 & 0.0000 & 0.6667 \\
2009 & 200 & 0.2370 & 0.0892 & 0.0400 & 0.6000 \\
2010 & 200 & 0.2577 & 0.0946 & 0.0000 & 0.6667 \\
2011 & 200 & 0.2746 & 0.0790 & 0.0000 & 0.5000 \\
2012 & 200 & 0.2514 & 0.0926 & 0.0571 & 0.7500 \\
2013 & 200 & 0.2384 & 0.0838 & 0.0000 & 0.5714 \\
$2014{ }^{*}$ & 150 & 0.2357 & 0.0905 & 0.0000 & 0.6000 \\
\hline
\end{tabular}

Source: Authors' own elaboration based on data provided by the CGPJ

Note: ${ }^{(*)} 2014$ include data available only until third quarter 
Table 2: Summary statistics of the percentage of labor court judgments ruling that the dismissal was fair $\left(2004-2014^{*}\right)$

\begin{tabular}{|c|c|c|c|c|c|}
\hline Province & Obs & Mean & Std. Dev. & Min & Max \\
\hline A Coruña & 43 & 0.2371 & 0.0434 & 0.1548 & 0.3264 \\
\hline Albacete & 43 & 0.2547 & 0.0700 & 0.1250 & 0.4762 \\
\hline Alicante & 43 & 0.1678 & 0.0328 & 0.1063 & 0.2306 \\
\hline Almeria & 43 & 0.2084 & 0.0523 & 0.1213 & 0.3300 \\
\hline Alava & 43 & 0.3429 & 0.0868 & 0.1905 & 0.5147 \\
\hline Asturias & 43 & 0.3180 & 0.0532 & 0.2024 & 0.4255 \\
\hline Avila & 43 & 0.1485 & 0.1389 & 0.0000 & 0.5714 \\
\hline Badajoz & 43 & 0.2936 & 0.0647 & 0.1575 & 0.4301 \\
\hline Barcelona & 43 & 0.2302 & 0.0384 & 0.1684 & 0.3256 \\
\hline Bizkaia & 43 & 0.2730 & 0.0484 & 0.1722 & 0.3581 \\
\hline Burgos & 43 & 0.3315 & 0.0818 & 0.2000 & 0.4857 \\
\hline Caceres & 43 & 0.3208 & 0.1184 & 0.1563 & 0.6667 \\
\hline Cadiz & 43 & 0.2746 & 0.0754 & 0.1197 & 0.4769 \\
\hline Cantabria & 43 & 0.2598 & 0.0515 & 0.1579 & 0.3670 \\
\hline Castellon & 43 & 0.2918 & 0.0661 & 0.1591 & 0.4267 \\
\hline Ciudad Real & 43 & 0.2750 & 0.0856 & 0.1389 & 0.4737 \\
\hline Cordoba & 43 & 0.3080 & 0.0644 & 0.1807 & 0.4857 \\
\hline Cuenca & 43 & 0.2998 & 0.1721 & 0.0649 & 0.8000 \\
\hline Gipuzkoa & 43 & 0.3070 & 0.0789 & 0.1667 & 0.4898 \\
\hline Girona & 43 & 0.2874 & 0.0722 & 0.1139 & 0.5000 \\
\hline Granada & 43 & 0.2599 & 0.0592 & 0.1346 & 0.3987 \\
\hline Guadalajara & 43 & 0.2327 & 0.1075 & 0.0728 & 0.5333 \\
\hline Huelva & 43 & 0.2352 & 0.0794 & 0.1033 & 0.4348 \\
\hline Huesca & 43 & 0.2805 & 0.1617 & 0.0000 & 0.5833 \\
\hline Illes Balears & 43 & 0.2432 & 0.0560 & 0.1392 & 0.3636 \\
\hline Jaen & 43 & 0.2964 & 0.0659 & 0.1515 & 0.4262 \\
\hline La Rioja & 43 & 0.2429 & 0.0856 & 0.0725 & 0.4364 \\
\hline Las Palmas & 43 & 0.2089 & 0.0381 & 0.1175 & 0.2857 \\
\hline Leon & 43 & 0.2431 & 0.0784 & 0.0917 & 0.4872 \\
\hline Lleida & 43 & 0.3251 & 0.1286 & 0.0667 & 0.6923 \\
\hline Lugo & 43 & 0.2815 & 0.1117 & 0.0408 & 0.5286 \\
\hline Madrid & 43 & 0.3022 & 0.0399 & 0.2344 & 0.3670 \\
\hline Malaga & 43 & 0.2696 & 0.0429 & 0.1636 & 0.3633 \\
\hline Murcia & 43 & 0.2649 & 0.0856 & 0.1330 & 0.4948 \\
\hline Navarra & 43 & 0.2814 & 0.0701 & 0.1200 & 0.4416 \\
\hline Ourense & 43 & 0.2266 & 0.0699 & 0.1000 & 0.3906 \\
\hline Palencia & 43 & 0.3751 & 0.1190 & 0.1000 & 0.6250 \\
\hline Pontevedra & 43 & 0.2779 & 0.0412 & 0.2010 & 0.3500 \\
\hline Salamanca & 43 & 0.2697 & 0.1086 & 0.1293 & 0.6341 \\
\hline S.C. Tenerife & 43 & 0.1899 & 0.0383 & 0.1228 & 0.2953 \\
\hline Segovia & 43 & 0.3066 & 0.1237 & 0.0000 & 0.6250 \\
\hline Sevilla & 43 & 0.2682 & 0.0504 & 0.1773 & 0.4514 \\
\hline Soria & 43 & 0.3003 & 0.1509 & 0.0000 & 0.6667 \\
\hline Tarragona & 43 & 0.3017 & 0.0650 & 0.1633 & 0.4479 \\
\hline Teruel & 43 & 0.3522 & 0.2172 & 0.0000 & 0.8333 \\
\hline Toledo & 43 & 0.1844 & 0.0661 & 0.0792 & 0.4679 \\
\hline Valencia & 43 & 0.2274 & 0.0387 & 0.1453 & 0.3202 \\
\hline Valladolid & 43 & 0.2879 & 0.0667 & 0.1316 & 0.4452 \\
\hline Zamora & 43 & 0.2676 & 0.1211 & 0.0545 & 0.5385 \\
\hline Zaragoza & 43 & 0.2193 & 0.0656 & 0.1016 & 0.3908 \\
\hline
\end{tabular}

Source: Authors' own elaboration based on data provided by the CGPJ

Note: ${ }^{(*)} 2014$ include data available only until third quarter 
Table 3: Description of variables

\begin{tabular}{|c|c|c|c|c|}
\hline VARIABLE & DEFINITION & SCALE/UNIT & PERIOD & SOURCE \\
\hline Court rulings & $\begin{array}{c}\text { Percentage of labour court judgments } \\
\text { ruling that the dismissal was fair or } \\
\text { justified }\end{array}$ & $\%$ & $\begin{array}{l}\text { By province, } \\
\text { 2004-2014 }\end{array}$ & CGPJ \\
\hline Reform 1 & $\begin{array}{c}2010 \text { labour market reform } \\
\text { enforcement period }\end{array}$ & Dummy & 2004-2014 & Self elaboration \\
\hline Reform 2 & $\begin{array}{l}2012 \text { labour market reform } \\
\text { enforcement period }\end{array}$ & Dummy & 2004-2014 & Self elaboration \\
\hline Interaction 1 & $\begin{array}{l}\text { Interaction between reform } 1 \text { and the } \\
\text { unemployment rate }\end{array}$ & $\%$ & $\begin{array}{l}\text { By province, } \\
\text { 2004-2014 }\end{array}$ & $\begin{array}{l}\text { Spanish National } \\
\text { Statistics Institute } \\
\text { (INE) }\end{array}$ \\
\hline Interaction 2 & $\begin{array}{l}\text { Interaction between reform } 2 \text { and the } \\
\text { unemployment rate }\end{array}$ & $\%$ & $\begin{array}{l}\text { By province, } \\
\text { 2004-2014 }\end{array}$ & $\begin{array}{l}\text { Spanish National } \\
\text { Statistics Institute } \\
\text { (INE) }\end{array}$ \\
\hline Unemployment rate & $\begin{array}{l}\text { Percentage of total workforce which is } \\
\text { unemployed and is looking for a paid } \\
\text { job }\end{array}$ & $\%$ & $\begin{array}{l}\text { By province, } \\
\text { 2004-2014 }\end{array}$ & $\begin{array}{l}\text { Spanish National } \\
\text { Statistics Institute } \\
\text { (INE) }\end{array}$ \\
\hline Temporary employment rate & $\begin{array}{l}\text { Percentage of total workforce which } \\
\text { has a fixed-term contract }\end{array}$ & $\%$ & $\begin{array}{l}\text { By province, } \\
\text { 2004-2014 }\end{array}$ & $\begin{array}{l}\text { Spanish National } \\
\text { Statistics Institute } \\
\text { (INE) }\end{array}$ \\
\hline Share of services & $\begin{array}{l}\text { Percentage of total workforce working } \\
\text { on services sector }\end{array}$ & $\%$ & $\begin{array}{l}\text { By province, } \\
\text { 2004-2014 }\end{array}$ & $\begin{array}{l}\text { Spanish National } \\
\text { Statistics Institute } \\
\text { (INE) }\end{array}$ \\
\hline Share of industry & $\begin{array}{l}\text { Percentage of total workforce working } \\
\text { on services sector }\end{array}$ & $\%$ & $\begin{array}{l}\text { By province, } \\
\text { 2004-2014 }\end{array}$ & $\begin{array}{l}\text { Spanish National } \\
\text { Statistics Institute } \\
\text { (INE) }\end{array}$ \\
\hline Share of construction & $\begin{array}{l}\text { Percentage of total workforce working } \\
\text { on services sector }\end{array}$ & $\%$ & $\begin{array}{l}\text { By province, } \\
\text { 2004-2014 }\end{array}$ & $\begin{array}{l}\text { Spanish National } \\
\text { Statistics Institute } \\
\text { (INE) }\end{array}$ \\
\hline $\begin{array}{c}\text { Proportion of dismissal lawsuits } \\
\text { analyzed (+) by professional judges } \\
\text { over total }\end{array}$ & $\begin{array}{l}\text { Percentage of labour court judgments } \\
\text { ruling that the dismissal was fair or } \\
\text { justified by professional judges over all } \\
\text { the dismissal lawsuits analyzed by all } \\
\text { judges }\end{array}$ & $\%$ & $\begin{array}{l}\text { By province, } \\
\text { 2004-2014 }\end{array}$ & CGPJ \\
\hline $\begin{array}{l}\text { Proportion of interim postings at the } \\
\text { labor courts }\end{array}$ & $\begin{array}{l}\text { Percentage of positions at the labour } \\
\text { courts held by interim judges }\end{array}$ & Fraction & $\begin{array}{l}\text { By province, } \\
\text { 2004-2014 }\end{array}$ & CGPJ \\
\hline $\begin{array}{l}\text { Judicial congestion rate (dismissals } \\
\text { lawsuits) }\end{array}$ & $\begin{array}{l}\text { Ratio between the sum of pending } \\
\text { cases in a labour court plus new cases } \\
\text { and the cases resolved in the same } \\
\text { quarter (related to dismissals cases) }\end{array}$ & Fraction & $\begin{array}{l}\text { By province, } \\
\text { 2004-2014 }\end{array}$ & CGPJ \\
\hline Out-of-court conciliations ratio & $\begin{array}{l}\text { Ratio of the number of out-of-court } \\
\text { conciliations finished with agreement } \\
\text { divided by the sum of those } \\
\text { conciliations (with agreement) and the } \\
\text { total number of dismissal lawsuits }\end{array}$ & $\%$ & $\begin{array}{c}\text { By province, } \\
\text { 2004-2014 }\end{array}$ & $\begin{array}{l}\text { CGPJ and Ministry of } \\
\text { Employment and } \\
\text { Social Security }\end{array}$ \\
\hline
\end{tabular}

Source: Authors' own elaboration 
Table 4: Descriptive statistics

\begin{tabular}{|c|c|c|c|c|c|}
\hline VARIABLE & Obs & Mean & Std. Dev. & Min & Max \\
\hline Court rulings & 1800 & 27.5221 & 10.1403 & 0 & 83.3333 \\
\hline Reform 1 & 3600 & 0.1389 & 0.3459 & 0 & 1 \\
\hline Reform 2 & 3600 & 0.0417 & 0.1999 & 0 & 1 \\
\hline Interaction 1 & 3400 & 3.2223 & 8.2209 & 0 & 40.6261 \\
\hline Interaction 2 & 3400 & 1.0850 & 5.2769 & 0 & 40.6261 \\
\hline Unemployment rate & 3400 & 14.6082 & 7.4209 & 2.1622 & 40.6261 \\
\hline Temporary employment rate & 1800 & 0.2891 & 0.0984 & 0 & 0.5949 \\
\hline Share of services & 3400 & 61.9545 & 8.0179 & 36.9500 & 88.5 \\
\hline Share of industry & 3400 & 17.3584 & 6.7819 & 3.2000 & 37.72 \\
\hline Share of construction & 3400 & 11.5821 & 3.1014 & 4.3000 & 23.8 \\
\hline $\begin{array}{c}\text { Proportion of dismissal lawsuits analyzed }(+) \text { by } \\
\text { professional judges over total }\end{array}$ & 3600 & 0.8315 & 0.1465 & 0 & 1 \\
\hline Proportion of interim postings at the labor courts & 1800 & 0.2738 & 0.6184 & 0 & 4.9444 \\
\hline Judicial congestion rate (dismissals lawsuits) & 3348 & 2.0017 & 0.71 & 0.8333 & 13 \\
\hline Out-of-court conciliations ratio & 2000 & 0.4852 & 0.1854 & 0 & 0.9310 \\
\hline
\end{tabular}

Source: Authors' own elaboration 
Table 5:

\begin{tabular}{|c|c|c|c|c|c|c|c|c|}
\hline \multicolumn{9}{|c|}{ OLS LINEAR REGRESSION } \\
\hline MODEL & 1 & 2 & 3 & 4 & 5 & 6 & 7 & $\begin{array}{l}8 \text { (excluding } \\
\text { Madrid and } \\
\text { Barcelona) }\end{array}$ \\
\hline DEPENDENT VARIABLE & \multicolumn{8}{|c|}{$\%$ of labor court judgments ruling that the dismissal was fair or justified } \\
\hline Difference in unemployment rate & & $-0.436^{* * * *}$ & $-0.363 * * *$ & $-0.386 * * *$ & $-0.346^{* * * *}$ & $-0.421 * * *$ & $-0.424 * * *$ & $-0.416^{* * *}$ \\
\hline Temporary employment rate & & & $\begin{array}{c}(0.074) \\
0.133 \\
(0.0937)\end{array}$ & $\begin{array}{c}(0.0928) \\
0.142 \\
(0.101)\end{array}$ & $\begin{array}{c}(0.0904) \\
0.118 \\
(0.101)\end{array}$ & $\begin{array}{c}(0.0916) \\
0.162 \\
(0.12)\end{array}$ & $\begin{array}{c}0.166 \\
0.12)\end{array}$ & $\begin{array}{c}0.17 \\
(0.123)\end{array}$ \\
\hline & & & & $(0.145)$ & $(0.145)$ & $(0.163)$ & $(0.165)$ & $(0.165)$ \\
\hline Share of industry & & & & 0.0872 & 0.0766 & -0.00262 & 0.00711 & -0.0105 \\
\hline & & & & $(0.257)$ & $(0.26)$ & $(0.255)$ & (0.256) & $(0.259)$ \\
\hline Share of construction & & & & -0.0858 & 0.1020 & 0.0382 & 0.0363 & 0.0413 \\
\hline & & & & $(0.212)$ & $(0.206)$ & $(0.203)$ & $(0.204)$ & (0.206) \\
\hline$\%$ of dismissal lawsuits analized (+) by professional & & & & & -0.0149 & -0.0225 & -0.0219 & -0.0212 \\
\hline & & & & & $(0.0171)$ & $(0.017)$ & $(0.0172)$ & $(0.0173)$ \\
\hline Proportion of temporary postings at the labor courts & & & & & 0.0018 & 0.0018 & 0.0019 & 0.0034 \\
\hline & & & & & (0.0026) & $(0.0031)$ & $(0.0031)$ & $(0.0040)$ \\
\hline Judicial congestion rate (dismissals lawsuits) & & & & & & 0.0059 & 0.0061 & 0.0063 \\
\hline & & & & & & $(0.0047)$ & $(0.0047)$ & $(0.0048)$ \\
\hline Judicial congestion rate (pre-trial conciliations) & & & & & & & $-0.0006^{*}$ & $-0.0006^{*}$ \\
\hline & & & & & & & $(0.0003)$ & $(0.0003)$ \\
\hline Constant & $0.279 * * *$ & $0.259 * * *$ & $0.220 * * *$ & 0.203 & 0.21 & 0.235 & 0.242 & 0.239 \\
\hline & $(0.0027)$ & $(0.0029)$ & $(0.0265)$ & $(0.1490)$ & $(0.1560)$ & $(0.1650)$ & $(0.1670)$ & $(0.1680)$ \\
\hline Provincial fixed effects & YES & YES & YES & YES & YES & YES & YES & YES \\
\hline Observations & 2,150 & 2,150 & 2,150 & 2,150 & 2,150 & 1,800 & 1,800 & 1,728 \\
\hline R-squared & 0.019 & 0.061 & 0.062 & 0.063 & 0.159 & 0.171 & 0.172 & 0.17 \\
\hline Clusters (provinces) & 50 & 50 & 50 & 50 & 50 & 50 & 50 & 48 \\
\hline 2010 reform with bootstrap estimation & $-0.0252 * * *$ & $0.0265 * * *$ & $0.0260^{* * *}$ & $0.0256 * * *$ & $0.0266 * * *$ & $0.0362 * * *$ & $0.0246 * * *$ & $0.0246 * * *$ \\
\hline Bootstrap (standard errors) for "2010 reform" & $(0.0049)$ & $(0.0061)$ & $(0.0061)$ & $(0.0068)$ & $(0.0064)$ & $(0.0077)$ & $(0.0082)$ & 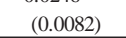 \\
\hline
\end{tabular}


Table 6:

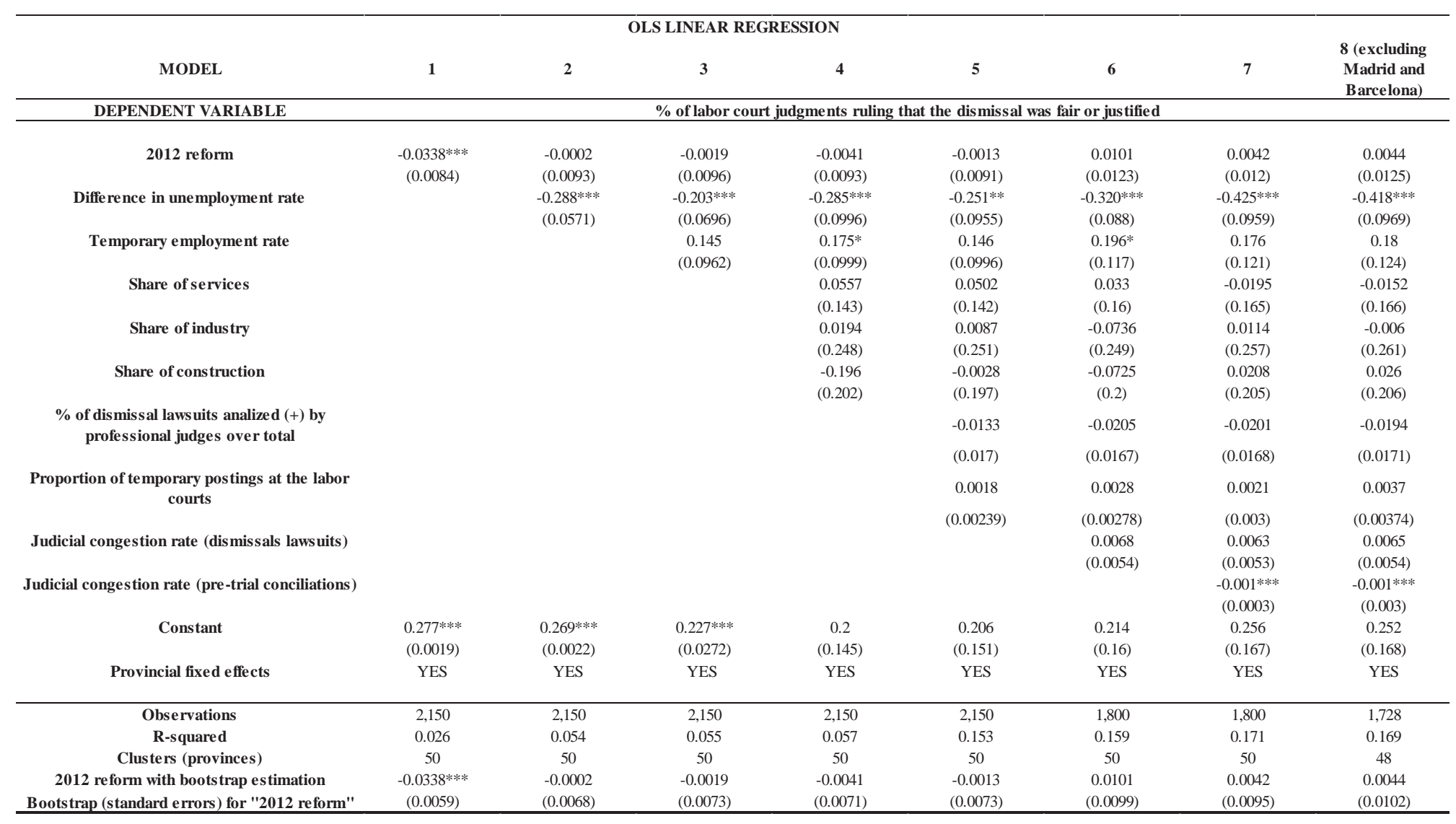


Table 7:

\begin{tabular}{|c|c|c|c|c|c|c|c|c|}
\hline \multicolumn{9}{|c|}{ ODDS-RATIO MODEL } \\
\hline MODEL & 1 & 2 & 3 & 4 & 5 & 6 & 7 & $\begin{array}{l}8 \text { (excluding } \\
\text { Madrid and } \\
\text { Barcelona) }\end{array}$ \\
\hline DEPENDENT VARIABLE & \multicolumn{8}{|c|}{ \% of labor court judgments ruling that the dismissal was fair or justified } \\
\hline 2010 reform & $\begin{array}{l}-0.0615^{* * *} \\
(0.0159)\end{array}$ & $\begin{array}{c}0.0492 * * * \\
(0.0182)\end{array}$ & $\begin{array}{l}0.0484^{* *} \\
(0.0185)\end{array}$ & $\begin{array}{l}0.0450^{* *} \\
(0.0192)\end{array}$ & $\begin{array}{l}0.0476^{* *} \\
(0.0188)\end{array}$ & $\begin{array}{c}0.0626 * * * \\
(0.0224)\end{array}$ & $\begin{array}{l}0.0501 * * \\
(0.0229)\end{array}$ & $\begin{array}{l}0.0505^{* *} \\
(0.0238)\end{array}$ \\
\hline Difference in unemployment rate & & $\begin{array}{c}-0.934^{* * *} \\
(0.153)\end{array}$ & $\begin{array}{l}-0.811^{* * *} \\
(0.175)\end{array}$ & $\begin{array}{c}-0.881 * * * \\
(0.226)\end{array}$ & $\begin{array}{c}-0.804^{* * *} \\
(0.22)\end{array}$ & $\begin{array}{c}-0.965 * * * \\
(0.218)\end{array}$ & $\begin{array}{c}-0.959 * * * \\
(0.223)\end{array}$ & $\begin{array}{c}-0.952 * * * \\
(0.227)\end{array}$ \\
\hline Temporary employment rate & & & $\begin{array}{c}0.224 \\
(0.223)\end{array}$ & $\begin{array}{c}0.309 \\
(0.244)\end{array}$ & $\begin{array}{c}0.274 \\
(0.263)\end{array}$ & $\begin{array}{c}0.379 \\
(0.329)\end{array}$ & $\begin{array}{c}0.385 \\
(0.329)\end{array}$ & $\begin{array}{c}0.39 \\
(0.341)\end{array}$ \\
\hline Share of services & & & & $\begin{array}{c}0.3 \\
(0.446)\end{array}$ & $\begin{array}{c}0.285 \\
(0.435)\end{array}$ & $\begin{array}{l}0.262 \\
(0.51)\end{array}$ & $\begin{array}{c}0.276 \\
(0.515)\end{array}$ & $\begin{array}{c}0.284 \\
(0.519)\end{array}$ \\
\hline Share of industry & & & & $\begin{array}{c}0.386 \\
(0.633)\end{array}$ & $\begin{array}{c}0.368 \\
(0.616)\end{array}$ & $\begin{array}{l}0.265 \\
(0.61)\end{array}$ & $\begin{array}{c}0.275 \\
(0.616)\end{array}$ & $\begin{array}{c}0.249 \\
(0.626)\end{array}$ \\
\hline Share of construction & & & & $\begin{array}{l}-0.0385 \\
(0.465)\end{array}$ & $\begin{array}{c}0.324 \\
(0.481)\end{array}$ & $\begin{array}{c}0.304 \\
(0.532)\end{array}$ & $\begin{array}{c}0.297 \\
(0.533)\end{array}$ & $\begin{array}{c}0.298 \\
(0.536)\end{array}$ \\
\hline $\begin{array}{l}\% \text { of dismissal lawsuits analized (+) by } \\
\text { professional judges over total }\end{array}$ & & & & & $\begin{array}{l}-0.0483 \\
(0.0667)\end{array}$ & $\begin{array}{l}-0.0632 \\
(0.0766)\end{array}$ & $\begin{array}{l}-0.0633 \\
(0.0772)\end{array}$ & $\begin{array}{l}-0.0618 \\
(0.0772)\end{array}$ \\
\hline $\begin{array}{c}\text { Proportion of temporary postings at the labor } \\
\text { courts }\end{array}$ & & & & & $\begin{array}{c}(0.000 /) \\
0.0015\end{array}$ & 0.0042 & 0.0043 & 0.0073 \\
\hline & & & & & $(0.0056)$ & $(0.0073)$ & $(0.0073)$ & $(0.0098)$ \\
\hline Judicial congestion rate (dismissals lawsuits) & & & & & & $\begin{array}{l}0.0233 \\
(0.019)\end{array}$ & $\begin{array}{c}0.0235 \\
(0.0189)\end{array}$ & $\begin{array}{c}0.0241 \\
(0.0192)\end{array}$ \\
\hline Judicial congestion rate (pre-trial & & & & & & & $\begin{array}{l}-0.0014 * \\
(0.0007)\end{array}$ & $\begin{array}{l}-0.0014^{*} \\
(0.0007)\end{array}$ \\
\hline Constant & $\begin{array}{l}0.426 * * * \\
(0.0063)\end{array}$ & $\begin{array}{l}0.382 * * * \\
(0.0072)\end{array}$ & $\begin{array}{l}0.317 * * * \\
(0.0634)\end{array}$ & $\begin{array}{l}0.0381 \\
(0.406)\end{array}$ & $\begin{array}{l}0.0673 \\
(0.405)\end{array}$ & $\begin{array}{l}0.0265 \\
(0.464)\end{array}$ & $\begin{array}{l}0.0302 \\
(0.467)\end{array}$ & $\begin{array}{l}0.0254 \\
(0.47)\end{array}$ \\
\hline Provincial fixed effects & YES & YES & YES & YES & YES & YES & YES & YES \\
\hline Observations & 2,150 & 2,150 & 2,150 & 2,150 & 2,150 & 1,800 & 1,800 & 1,728 \\
\hline R-squared & 0.015 & 0.04 & 0.041 & 0.042 & 0.088 & 0.092 & 0.093 & 0.091 \\
\hline Clusters (provinces) & 50 & 50 & 50 & 50 & 50 & 50 & 50 & 48 \\
\hline 2010 reform with boots trap estimation & $-0.0615^{* * *}$ & $0.0492 * * *$ & $0.0484^{* * *}$ & $0.0450 * * *$ & $0.0476^{* * *}$ & $0.0626 * * *$ & $0.0501^{* * *}$ & $0.0505 * * *$ \\
\hline Bootstrap (standard errors) for "2010 reform" & $(0.0119)$ & $(0.0147)$ & $(0.0150)$ & $(0.0146)$ & $(0.0156)$ & $(0.0176)$ & $(0.0168)$ & $(0.0172)$ \\
\hline
\end{tabular}


Table 8:

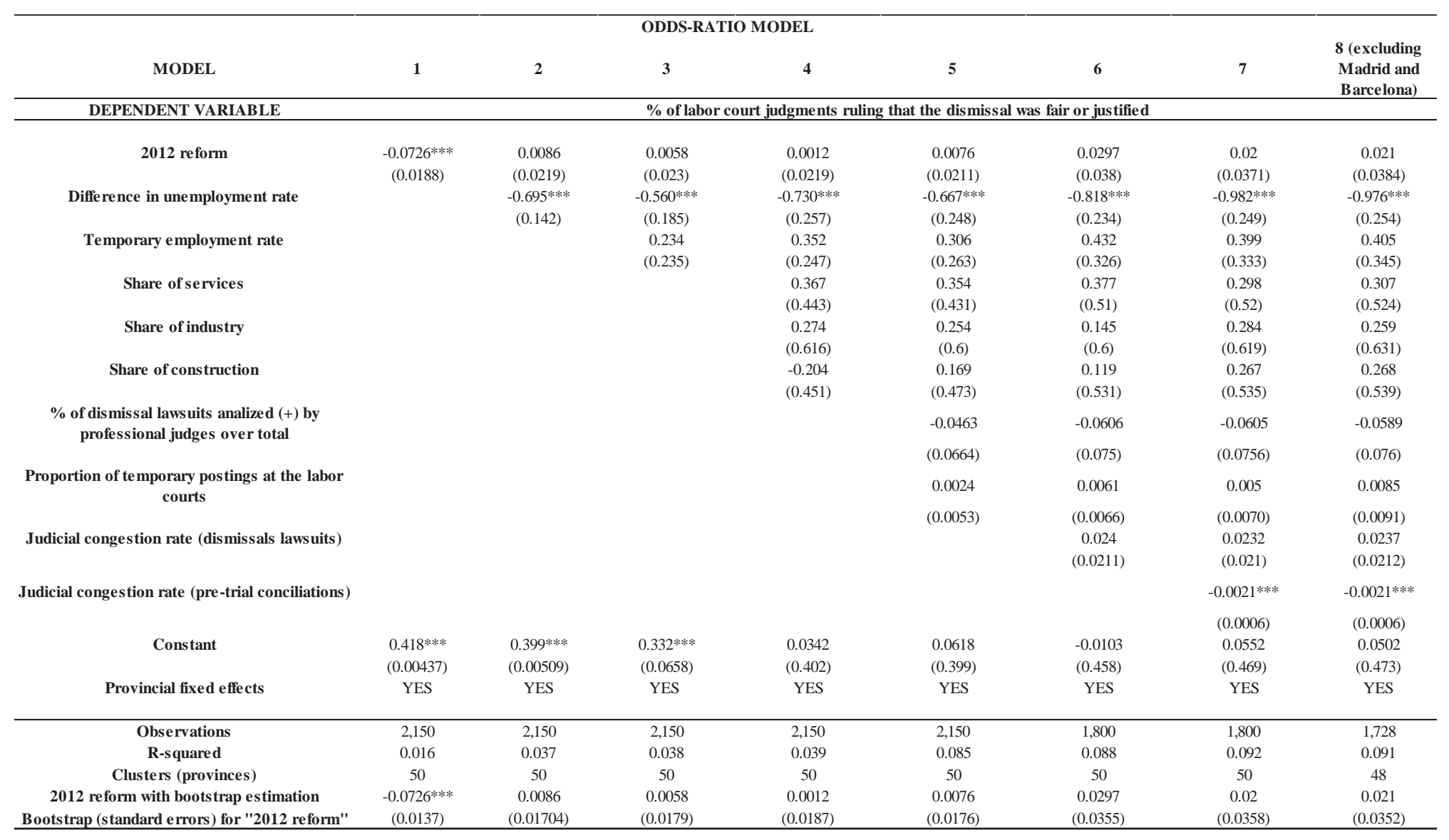


Table 9:

\begin{tabular}{|c|c|c|c|c|c|c|c|c|}
\hline \multicolumn{9}{|c|}{ OLS LINEAR REGRESSION } \\
\hline MODEL & 1 & 2 & 3 & 4 & 5 & 6 & 7 & $\begin{array}{l}8 \text { (excluding } \\
\text { Madrid and } \\
\text { Barcelona) }\end{array}$ \\
\hline DEPENDENT VARIABLE & \multicolumn{8}{|c|}{$\%$ of labor court judgments ruling that the dismissal was fair or justified } \\
\hline \multirow[t]{2}{*}{2010 interaction } & -0.0795 & $0.272 * * *$ & $0.259 * * *$ & $0.260^{* * *}$ & $0.335 * * *$ & $0.224^{* *}$ & $0.235 * * *$ & $0.230^{* * *}$ \\
\hline & $(0.078)$ & $(0.0887)$ & $(0.0869)$ & $(0.0924)$ & $(0.0815)$ & $(0.0842)$ & $(0.0838)$ & $(0.0857)$ \\
\hline \multirow[t]{2}{*}{2010 reform } & -0.0066 & -0.0212 & -0.0192 & -0.0207 & $-0.0329 *$ & -0.0049 & -0.024 & -0.0234 \\
\hline & $(0.0195)$ & $(0.0196)$ & $(0.0193)$ & $(0.0212)$ & $(0.019)$ & $(0.0213)$ & $(0.0221)$ & $(0.0227)$ \\
\hline \multirow[t]{2}{*}{ Difference in unemployment rate } & & $-0.568^{* * * *}$ & $-0.519 * * *$ & $-0.542 * * *$ & $-0.546 * * *$ & $-0.522 * * *$ & $-0.534^{* * * *}$ & $-0.525 * * *$ \\
\hline & & $(0.072)$ & $(0.0746)$ & $(0.0934)$ & $(0.0831)$ & $(0.086)$ & $(0.0892)$ & $(0.0907)$ \\
\hline \multirow{2}{*}{ Temporary employment rate } & & & 0.0771 & 0.0889 & 0.0498 & 0.12 & 0.123 & 0.127 \\
\hline & & & $(0.0874)$ & $(0.0955)$ & $(0.0919)$ & $(0.114)$ & $(0.115)$ & $(0.118)$ \\
\hline \multirow[t]{2}{*}{ Share of services } & & & & 0.0345 & 0.0332 & -0.0131 & -0.0098 & -0.0060 \\
\hline & & & & $(0.142)$ & $(0.141)$ & $(0.159)$ & $(0.16)$ & $(0.161)$ \\
\hline \multirow[t]{2}{*}{ Share of industry } & & & & 0.0006 & -0.0360 & -0.0585 & -0.0469 & -0.0614 \\
\hline & & & & $(0.261)$ & $(0.253)$ & $(0.245)$ & $(0.247)$ & $(0.25)$ \\
\hline \multirow{2}{*}{ Share of construction } & & & & -0.0403 & 0.1660 & 0.0790 & 0.0798 & 0.0829 \\
\hline & & & & $(0.205)$ & $(0.194)$ & $(0.195)$ & $(0.196)$ & $(0.198)$ \\
\hline \multirow{2}{*}{$\begin{array}{l}\% \text { of dismissal lawsuits analized (+) by professional } \\
\text { judges over total }\end{array}$} & & & & & -0.0175 & -0.0239 & -0.0229 & -0.0218 \\
\hline & & & & & $(0.0165)$ & $(0.0165)$ & $(0.0167)$ & $(0.0168)$ \\
\hline \multirow[t]{2}{*}{ Proportion of temporary postings at the labor courts } & & & & & 0.0031 & 0.0022 & 0.0023 & 0.0039 \\
\hline & & & & & $(0.0029)$ & $(0.0034)$ & $(0.0034)$ & $(0.0043)$ \\
\hline \multirow[t]{2}{*}{ Judicial congestion rate (dismissals lawsuits) } & & & & & & 0.0052 & 0.0054 & 0.0057 \\
\hline & & & & & & $(0.0047)$ & $(0.0047)$ & $(0.0047)$ \\
\hline \multirow[t]{2}{*}{ Judicial congestion rate (pre-trial conciliations) } & & & & & & & $-0.0007 * *$ & $-0.0007 * *$ \\
\hline & & & & & & & $(0.0003)$ & $(0.0003)$ \\
\hline \multirow[t]{2}{*}{ Constant } & $0.279 * * *$ & $0.252 * * *$ & $0.230^{* * *}$ & 0.209 & 0.22 & 0.238 & 0.251 & 0.248 \\
\hline & $(0.0027)$ & $(0.0030)$ & $(0.0252)$ & $(0.147)$ & $(0.15)$ & $(0.158)$ & $(0.16)$ & $(0.161)$ \\
\hline Provincial fixed effects & YES & YES & YES & YES & YES & YES & YES & YES \\
\hline Observations & 2,150 & 2,150 & 2,150 & 2,150 & 2,150 & 1,800 & 1,800 & 1,728 \\
\hline R-squared & 0.02 & 0.07 & 0.07 & 0.07 & 0.171 & 0.176 & 0.177 & 0.175 \\
\hline Clusters (provinces) & 50 & 50 & 50 & 50 & 50 & 50 & 50 & 48 \\
\hline 2010 interaction with boots trap estimation & -0.0795 & $0.272 * * *$ & $0.259 * * *$ & $0.260^{* * *}$ & $0.335 * * *$ & $0.224^{* * *}$ & $0.235 * * *$ & $0.230^{* * *}$ \\
\hline Bootstrap (standard errors) for "2010 interaction" & $(0.0613)$ & $(0.0661)$ & $(0.0690)$ & $(0.0787)$ & $(0.064)$ & $(0.0672)$ & $(0.0662)$ & $(0.0706)$ \\
\hline
\end{tabular}




\section{Table 10:}

\begin{tabular}{|c|c|c|c|c|c|c|c|c|}
\hline \multicolumn{8}{|c|}{ OLS LINEAR REGRESSION } & \multirow[b]{2}{*}{$\begin{array}{l}8 \text { (excluding } \\
\text { Madrid and } \\
\text { Barcelona) }\end{array}$} \\
\hline MODEL & 1 & 2 & 3 & 4 & 5 & 6 & 7 & \\
\hline DEPENDENT VARIABLE & \multicolumn{8}{|c|}{$\%$ of labor court judgments ruling that the dismissal was fair or justified } \\
\hline 2012 interaction & 0.0676 & $0.220^{*}$ & $0.210^{*}$ & $0.228^{*}$ & $0.279 * *$ & 0.0244 & 0.0987 & 0.094 \\
\hline & $(0.12)$ & $(0.123)$ & $(0.122)$ & $(0.13)$ & $(0.116)$ & $(0.14)$ & $(0.143)$ & $(0.146)$ \\
\hline 2012 reform & -0.0507 & -0.0513 & -0.0504 & -0.0572 & $-0.0660^{*}$ & 0.0043 & -0.0194 & -0.0182 \\
\hline & $(0.0354)$ & $(0.0359)$ & $(0.0358)$ & $(0.0378)$ & $(0.0337)$ & $(0.0426)$ & $(0.0433)$ & $(0.0447)$ \\
\hline Difference in unemployment rate & & $-0.322 * * *$ & $-0.247^{* * *}$ & $-0.350^{* * * *}$ & $-0.332 * * *$ & $-0.324^{* * *}$ & $-0.441 * * *$ & $-0.433^{* * *}$ \\
\hline & & $(0.0571)$ & $(0.0631)$ & $(0.0928)$ & $(0.0864)$ & $(0.0868)$ & $(0.0952)$ & $(0.0963)$ \\
\hline Temporary employment rate & & & 0.126 & 0.158 & 0.126 & $0.195^{*}$ & 0.17 & 0.174 \\
\hline & & & $(0.0914)$ & $(0.0955)$ & $(0.0942)$ & $(0.115)$ & $(0.119)$ & $(0.122)$ \\
\hline Share of services & & & & 0.0681 & 0.0651 & 0.0333 & -0.0196 & -0.0153 \\
\hline & & & & $(0.14)$ & $(0.14)$ & $(0.16)$ & $(0.164)$ & $(0.165)$ \\
\hline Share of industry & & & & -0.0573 & -0.086 & -0.0778 & -0.0031 & -0.0197 \\
\hline & & & & $(0.257)$ & $(0.252)$ & $(0.252)$ & $(0.258)$ & $(0.262)$ \\
\hline Share of construction & & & & -0.205 & -0.0113 & -0.0728 & 0.0225 & 0.0276 \\
\hline & & & & $(0.201)$ & $(0.194)$ & $(0.2)$ & $(0.204)$ & $(0.205)$ \\
\hline$\%$ of dismissal lawsuits analized (+) by professional & & & & & -0.015 & -0.0206 & -0.0205 & -0.0197 \\
\hline judges over total & & & & & $(0.017)$ & $(0.017)$ & $(0.017)$ & $(0.0173)$ \\
\hline Proportion of temporary postings at the labor & & & & & 0.0028 & 0.0029 & 0.0023 & 0.0040 \\
\hline & & & & & $(0.0025)$ & $(0.0028)$ & $(0.0030)$ & $(0.0038)$ \\
\hline Judicial congestion rate (dismissals lawsuits) & & & & & & 0.0068 & 0.0062 & 0.0064 \\
\hline & & & & & & $(0.0054)$ & $(0.0052)$ & $(0.0053)$ \\
\hline Judicial congestion rate (pre-trial conciliations) & & & & & & & $-0.0010^{* * * *}$ & $-0.0010^{* * * *}$ \\
\hline & & & & & & & $(0.0003)$ & $(0.0003)$ \\
\hline Constant & $0.277 * * *$ & $0.268 * * *$ & $0.232 * * *$ & 0.209 & 0.218 & 0.214 & 0.26 & 0.257 \\
\hline Provincial fixed effects & $\begin{array}{l}(0.0019) \\
\text { YES }\end{array}$ & $\begin{array}{l}(0.0019) \\
\text { YES }\end{array}$ & $\begin{array}{l}(0.0262) \\
\text { YES }\end{array}$ & $\begin{array}{l}(0.144) \\
\text { YES }\end{array}$ & $\begin{array}{c}(0.15) \\
\text { YES }\end{array}$ & $\begin{array}{c}(0.159) \\
\text { YES }\end{array}$ & $\begin{array}{c}(0.166) \\
\text { YES }\end{array}$ & $\begin{array}{c}(0.167) \\
\text { YES }\end{array}$ \\
\hline Observations & 2,150 & 2,150 & 2,150 & 2,150 & 2,150 & 1,800 & 1,800 & 1,728 \\
\hline R-squared & 0.026 & 0.059 & 0.06 & 0.062 & 0.16 & 0.159 & 0.171 & 0.169 \\
\hline Clusters (provinces) & 50 & 50 & 50 & 50 & 50 & 50 & 50 & 48 \\
\hline 2012 interaction with bootstrap estimation & 0.0676 & $0.220^{*}$ & $0.210^{*}$ & $0.228 * *$ & $0.279 * * *$ & 0.0244 & 0.0987 & 0.094 \\
\hline Bootstrap (standard errors) for "2012 interaction" & $(0.0945)$ & $(0.0981)$ & $(0.0892)$ & $(0.1063)$ & $(0.0980)$ & $(0.1198)$ & $(0.1142)$ & $(0.1141)$ \\
\hline
\end{tabular}




\section{Table 11:}

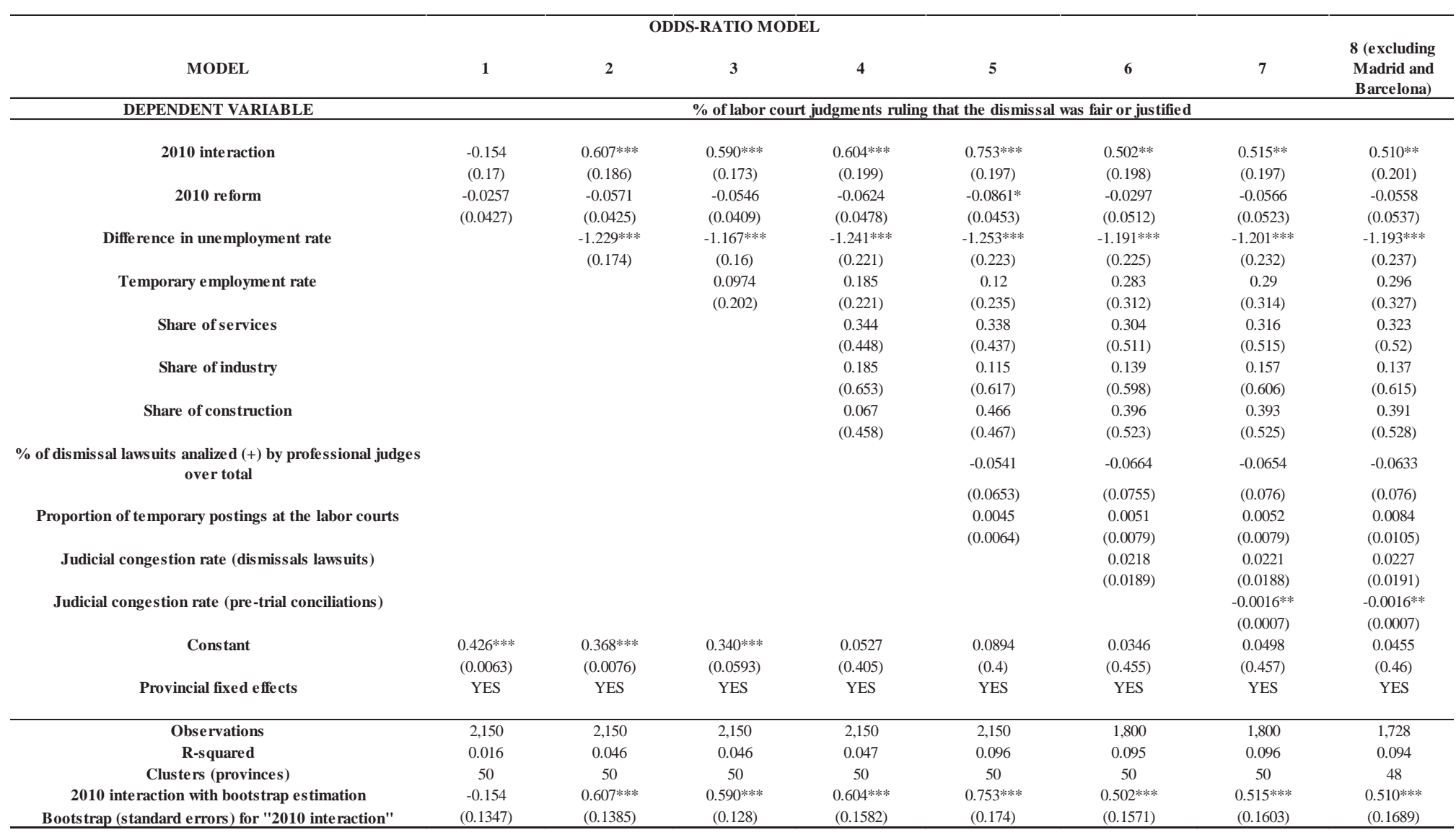


Table 12:

\begin{tabular}{|c|c|c|c|c|c|c|c|c|}
\hline \multicolumn{9}{|c|}{ ODDS-RATIO MODEL } \\
\hline MODEL & 1 & 2 & 3 & 4 & 5 & 6 & 7 & $\begin{array}{l}8 \text { (excluding } \\
\text { Madrid and } \\
\text { Barcelona) }\end{array}$ \\
\hline DEPENDENT VARIABLE & \multicolumn{8}{|c|}{ \% of labor court judgments ruling that the dismissal was fair or justified } \\
\hline \multirow[t]{2}{*}{2012 interaction } & 0.101 & $0.464^{*}$ & $0.449 *$ & $0.491^{*}$ & $0.595 * *$ & -0.0167 & 0.103 & 0.0898 \\
\hline & $(0.269)$ & $(0.271)$ & $(0.262)$ & $(0.29)$ & $(0.269)$ & $(0.386)$ & $(0.388)$ & $(0.399)$ \\
\hline \multirow[t]{2}{*}{2012 reform } & -0.098 & -0.0993 & -0.0979 & -0.113 & $-0.130^{*}$ & 0.0336 & -0.0047 & -0.0006 \\
\hline & $(0.0795)$ & $(0.0806)$ & $(0.0799)$ & $(0.0855)$ & $(0.0777)$ & $(0.124)$ & $(0.125)$ & $(0.129)$ \\
\hline \multirow[t]{2}{*}{ Difference in unemployment rate } & & $-0.769 * * *$ & $-0.654 * * *$ & $-0.871^{* * *}$ & $-0.840 * * *$ & $-0.816^{* * *}$ & $-0.999 * * *$ & $-0.991 * * *$ \\
\hline & & $(0.139)$ & $(0.159)$ & $(0.226)$ & $(0.221)$ & $(0.221)$ & $(0.233)$ & $(0.237)$ \\
\hline \multirow{2}{*}{ Temporary employment rate } & & & 0.193 & 0.316 & 0.263 & 0.432 & 0.393 & 0.4 \\
\hline & & & $(0.22)$ & $(0.233)$ & $(0.248)$ & $(0.317)$ & $(0.324)$ & $(0.336)$ \\
\hline \multirow[t]{2}{*}{ Share of services } & & & & 0.394 & 0.385 & 0.377 & 0.298 & 0.307 \\
\hline & & & & $(0.441)$ & $(0.431)$ & $(0.509)$ & $(0.52)$ & $(0.524)$ \\
\hline \multirow[t]{2}{*}{ Share of industry } & & & & 0.109 & 0.0525 & 0.148 & 0.268 & 0.246 \\
\hline & & & & $(0.656)$ & $(0.625)$ & $(0.629)$ & $(0.641)$ & $(0.654)$ \\
\hline \multirow[t]{2}{*}{ Share of cons truction } & & & & -0.225 & 0.151 & 0.119 & 0.269 & 0.27 \\
\hline & & & & $(0.45)$ & $(0.468)$ & $(0.531)$ & $(0.536)$ & $(0.54)$ \\
\hline \multirow{2}{*}{$\begin{array}{l}\% \text { of dismissal lawsuits analized }(+) \text { by professional } \\
\text { judges over total }\end{array}$} & & & & & -0.0499 & -0.0605 & -0.0609 & -0.0592 \\
\hline & & & & & $(0.0666)$ & $(0.076)$ & $(0.0764)$ & $(0.0768)$ \\
\hline \multirow[t]{2}{*}{$\begin{array}{l}\text { Proportion of temporary postings at the labor } \\
\text { courts }\end{array}$} & & & & & 0.0045 & 0.0061 & 0.0052 & 0.0087 \\
\hline & & & & & $(0.0055)$ & $(0.0068)$ & $(0.0072)$ & $(0.0093)$ \\
\hline \multirow[t]{2}{*}{ Judicial congestion rate (dismissals lawsuits) } & & & & & & 0.024 & 0.0231 & 0.0236 \\
\hline & & & & & & $(0.0208)$ & $(0.0207)$ & $(0.0209)$ \\
\hline \multirow[t]{2}{*}{ Judicial congestion rate (pre-trial conciliations) } & & & & & & & $-0.0021 * * *$ & $-0.0021 * * *$ \\
\hline & & & & & & & $(0.0006)$ & $(0.0006)$ \\
\hline \multirow[t]{2}{*}{ Constant } & $0.418^{* * *}$ & $0.397 * * *$ & $0.342 * * *$ & 0.0533 & 0.0875 & -0.0109 & 0.0602 & 0.0547 \\
\hline & $(0.0044)$ & $(0.0045)$ & $(0.0622)$ & $(0.404)$ & $(0.401)$ & $(0.46)$ & $(0.471)$ & $(0.475)$ \\
\hline Provincial fixed effects & YES & YES & YES & YES & YES & YES & YES & YES \\
\hline Observations & 2,150 & 2,150 & 2,150 & 2,150 & 2,150 & 1,800 & 1,800 & 1,728 \\
\hline R-squared & 0.016 & 0.04 & 0.041 & 0.042 & 0.09 & 0.088 & 0.092 & 0.091 \\
\hline Clusters (provinces) & 50 & 50 & 50 & 50 & 50 & 50 & 50 & 48 \\
\hline 2012 interaction with bootstrap estimation & 0.101 & $0.464 * *$ & $0.449 * *$ & $0.491 * *$ & $0.595 * *$ & -0.0167 & 0.103 & 0.0898 \\
\hline Bootstrap (standard errors) for "2012 interaction" & $(0.2077)$ & $(0.2110)$ & $(0.2019)$ & $(0.2338)$ & $(0.2377)$ & $(0.3268)$ & $(0.3076)$ & $(0.3295)$ \\
\hline
\end{tabular}




\section{Table 13:}

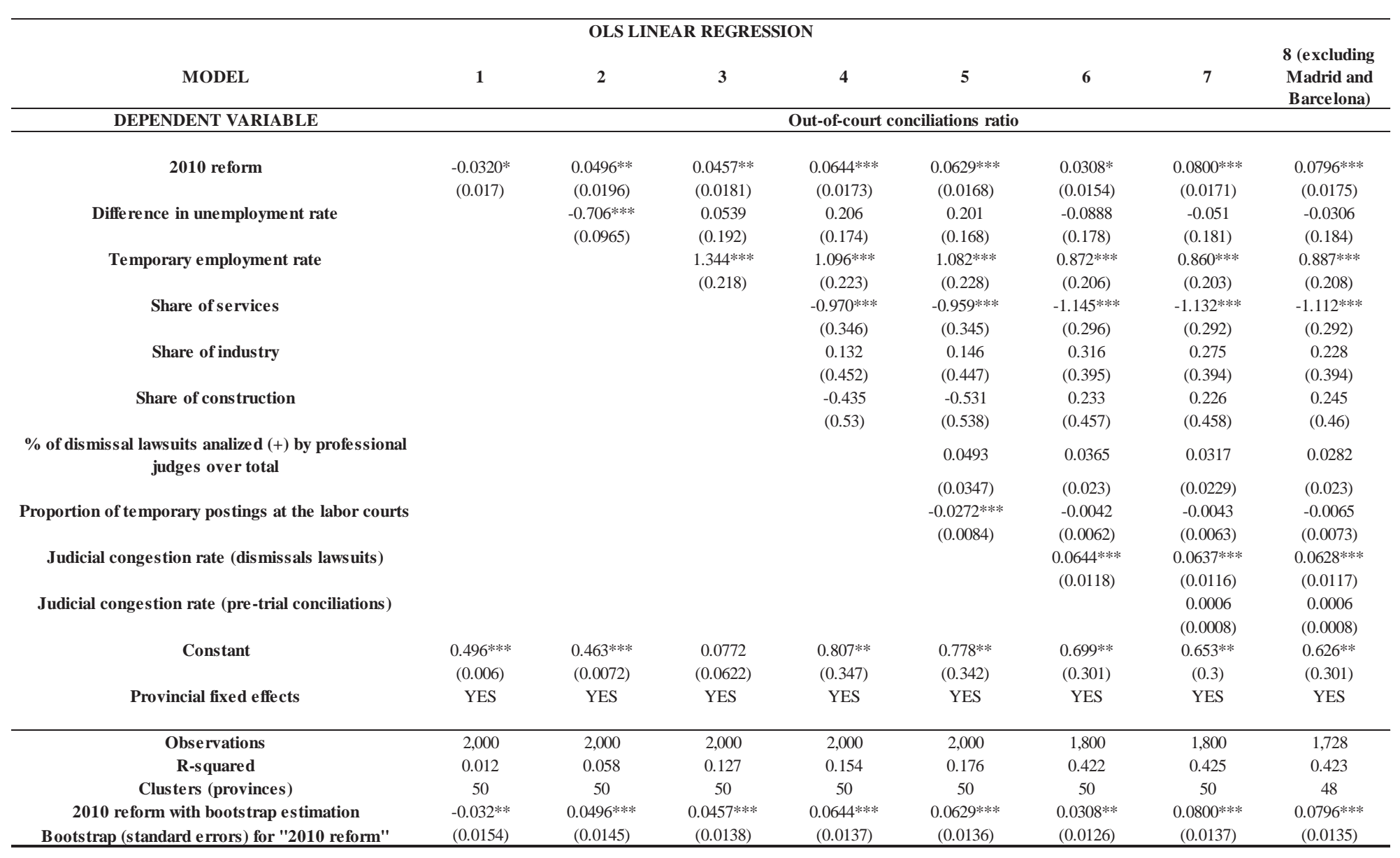




\section{Table 14:}

\begin{tabular}{|c|c|c|c|c|c|c|c|c|}
\hline \multicolumn{9}{|c|}{ OLS LINEAR REGRESSION } \\
\hline MODEL & 1 & 2 & 3 & 4 & 5 & 6 & 7 & $\begin{array}{c}8 \text { (excluding } \\
\text { Madrid and } \\
\text { Barcelona) }\end{array}$ \\
\hline DEPENDENT VARIABLE & \multicolumn{8}{|c|}{ Out-of-court conciliations ratio } \\
\hline 2012 reform & $\begin{array}{c}0.0832 * * * \\
(0.0176)\end{array}$ & $\begin{array}{l}0.234^{* * *} \\
(0.0119)\end{array}$ & $\begin{array}{l}0.223^{* * *} \\
(0.0121)\end{array}$ & $\begin{array}{l}0.226^{* * * *} \\
(0.0119)\end{array}$ & $\begin{array}{l}0.222 * * * \\
(0.0113)\end{array}$ & $\begin{array}{l}0.116^{* * *} \\
(0.0137)\end{array}$ & $\begin{array}{l}0.115^{* * *} \\
(0.0128)\end{array}$ & $\begin{array}{l}0.113^{* * * *} \\
(0.0129)\end{array}$ \\
\hline Difference in unemployment rate & & $\begin{array}{l}-1.270^{* * *} \\
(0.102)\end{array}$ & $\begin{array}{l}-0.617 * * * \\
(0.182)\end{array}$ & $\begin{array}{l}-0.335^{*} \\
(0.17)\end{array}$ & $\begin{array}{c}-0.334^{*} \\
(0.17)\end{array}$ & $\begin{array}{l}-0.234 \\
(0.188)\end{array}$ & $\begin{array}{l}-0.234 \\
(0.193)\end{array}$ & $\begin{array}{l}-0.209 \\
(0.196)\end{array}$ \\
\hline Temporary employment rate & & & $\begin{array}{l}1.118^{* * *} \\
(0.208)\end{array}$ & $\begin{array}{l}0.890 * * * \\
(0.208)\end{array}$ & $\begin{array}{l}0.894 * * * \\
(0.211)\end{array}$ & $\begin{array}{l}0.845 * * * \\
(0.206)\end{array}$ & $\begin{array}{l}0.845 * * * \\
(0.206)\end{array}$ & $\begin{array}{c}0.876^{* * *} \\
(0.21)\end{array}$ \\
\hline Share of services & & & & $\begin{array}{l}-0.841 * * * \\
(0.308)\end{array}$ & $\begin{array}{c}-0.838 * * * \\
(0.311)\end{array}$ & $\begin{array}{l}-1.059 * * * \\
(0.28)\end{array}$ & $\begin{array}{c}-1.057 * * * \\
(0.277)\end{array}$ & $\begin{array}{c}-1.039 * * * \\
(0.278)\end{array}$ \\
\hline Share of industry & & & & $\begin{array}{c}0.163 \\
(0.386)\end{array}$ & $\begin{array}{c}0.168 \\
(0.384)\end{array}$ & $\begin{array}{c}0.281 \\
(0.375)\end{array}$ & $\begin{array}{c}0.284 \\
(0.381)\end{array}$ & $\begin{array}{c}0.244 \\
(0.381)\end{array}$ \\
\hline Share of construction & & & & $\begin{array}{l}-0.184 \\
(0.45)\end{array}$ & $\begin{array}{l}-0.279 \\
(0.461)\end{array}$ & $\begin{array}{c}0.19 \\
(0.43)\end{array}$ & $\begin{array}{c}0.19 \\
(0.431)\end{array}$ & $\begin{array}{c}0.205 \\
(0.433)\end{array}$ \\
\hline $\begin{array}{c}\% \text { of dismissal lawsuits analized }(+) \text { by } \\
\text { professional judges over total }\end{array}$ & & & & & $\begin{array}{l}0.0249 \\
(0.0263)\end{array}$ & $\begin{array}{c}0.0302 \\
(0.0212)\end{array}$ & $\begin{array}{c}0.0299 \\
(0.0211)\end{array}$ & $\begin{array}{l}0.0282 \\
(0.0215)\end{array}$ \\
\hline $\begin{array}{l}\text { Proportion of temporary postings at the labor } \\
\text { courts }\end{array}$ & & & & & $-0.0111^{* *}$ & -0.0016 & -0.0016 & -0.0019 \\
\hline Judicial congestion rate (dismissals lawsuits) & & & & & $(0.0053)$ & $\begin{array}{c}(0.0051) \\
0.0567 * * * \\
(0.0111)\end{array}$ & $\begin{array}{c}(0.0051) \\
0.0567 * * * \\
(0.0112)\end{array}$ & $\begin{array}{c}(0.0064) \\
0.0564 * * * \\
(0.0112)\end{array}$ \\
\hline Judicial congestion rate (pre-trial conciliations) & & & & & & & -0.0003 & -0.0003 \\
\hline & & & & & & & $(0.0006)$ & $(0.0006)$ \\
\hline Constant & $\begin{array}{l}0.471 * * * \\
(0.0031)\end{array}$ & $\begin{array}{l}0.436 * * * \\
(0.0022)\end{array}$ & $\begin{array}{c}0.116^{*} \\
(0.0592)\end{array}$ & $\begin{array}{l}0.730^{* *} \\
(0.303)\end{array}$ & $\begin{array}{l}0.718^{* *} \\
(0.303)\end{array}$ & $\begin{array}{l}0.680^{* *} \\
(0.284)\end{array}$ & $\begin{array}{l}0.679 * * \\
(0.282)\end{array}$ & $\begin{array}{l}0.650^{* *} \\
(0.284)\end{array}$ \\
\hline Provincial fixed effects & YES & YES & YES & YES & YES & YES & YES & YES \\
\hline Observations & 2,000 & 2,000 & 2,000 & 2,000 & 2,000 & 1,800 & 1,800 & 1,728 \\
\hline R-squared & 0.052 & 0.283 & 0.331 & 0.354 & 0.363 & 0.457 & 0.457 & 0.452 \\
\hline Clusters (provinces) & 50 & 50 & 50 & 50 & 50 & 50 & 50 & 48 \\
\hline 2012 reform with bootstrap estimation & $0.0832^{* * *}$ & $0.234^{* * *}$ & $0.223^{* * *}$ & $0.226^{* * *}$ & $0.222 * * *$ & $0.116^{* * *}$ & $0.115^{* * *}$ & $0.113^{* * *}$ \\
\hline Bootstrap (standard errors) for "2012 reform" & $(0.0140)$ & $(0.0087)$ & $(0.009)$ & $(0.0088)$ & $(0.0082)$ & $(0.0100)$ & $(0.0099)$ & $(0.0102)$ \\
\hline
\end{tabular}


Table 15:

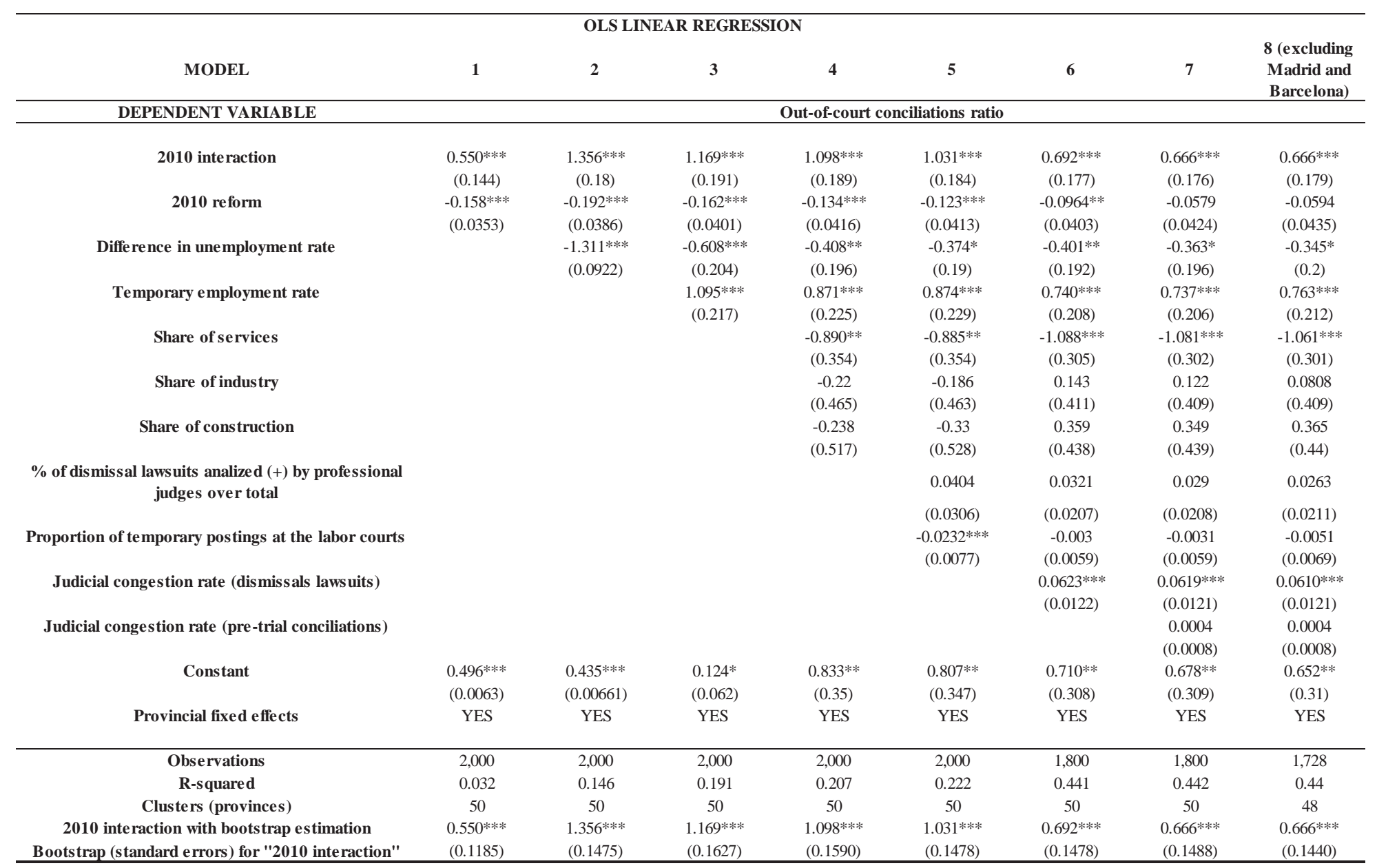


Table 16:

\begin{tabular}{|c|c|c|c|c|c|c|c|c|}
\hline \multicolumn{9}{|c|}{ OLS LINEAR REGRESSION } \\
\hline MODEL & 1 & 2 & 3 & 4 & 5 & 6 & 7 & $\begin{array}{l}8 \text { (excluding } \\
\text { Madrid and } \\
\text { Barcelona) }\end{array}$ \\
\hline DEPENDENT VARIABLE & \multicolumn{8}{|c|}{ Out-of-court conciliations ratio } \\
\hline 2012 interaction & $\begin{array}{c}-0.12 \\
(0.173)\end{array}$ & $\begin{array}{c}0.500 * * \\
(0.187)\end{array}$ & $\begin{array}{c}0.408^{* *} \\
(0.2)\end{array}$ & $\begin{array}{l}0.287 \\
(0.21)\end{array}$ & $\begin{array}{c}0.248 \\
(0.204)\end{array}$ & $\begin{array}{l}0.0665 \\
(0.24)\end{array}$ & $\begin{array}{l}0.0703 \\
(0.233)\end{array}$ & $\begin{array}{c}0.103 \\
(0.235)\end{array}$ \\
\hline \multirow[t]{2}{*}{2012 reform } & $0.114^{* *}$ & $0.115^{* *}$ & $0.126^{* *}$ & $0.158^{* * *}$ & $0.163 * * *$ & 0.0999* & $0.0986^{*}$ & 0.0879 \\
\hline & $(0.0515)$ & $(0.0493)$ & $(0.0511)$ & $(0.0542)$ & $(0.0529)$ & $(0.058)$ & $(0.0551)$ & $(0.0552)$ \\
\hline \multirow[t]{2}{*}{ Difference in unemployment rate } & & $-1.331 * * *$ & $-0.685 * * *$ & $-0.400^{* *}$ & $-0.391 * *$ & -0.243 & -0.245 & -0.226 \\
\hline & & $(0.112)$ & $(0.196)$ & $(0.186)$ & $(0.186)$ & $(0.197)$ & $(0.2)$ & $(0.204)$ \\
\hline \multirow[t]{2}{*}{ Temporary employment rate } & & & $1.086^{* * *}$ & $0.871^{* * *}$ & $0.877^{* * *}$ & $0.841^{* * *}$ & $0.841^{* * *}$ & $0.870^{* * *}$ \\
\hline & & & $(0.211)$ & $(0.215)$ & $(0.218)$ & $(0.21)$ & $(0.211)$ & $(0.216)$ \\
\hline \multirow[t]{2}{*}{ Share of services } & & & & $-0.834 * * *$ & $-0.833^{* * * *}$ & $-1.058 * * *$ & $-1.057^{* * * *}$ & $-1.039 * * *$ \\
\hline & & & & $(0.305)$ & $(0.308)$ & $(0.279)$ & $(0.277)$ & $(0.277)$ \\
\hline \multirow[t]{2}{*}{ Share of industry } & & & & 0.0731 & 0.0901 & 0.27 & 0.274 & 0.229 \\
\hline & & & & $(0.402)$ & $(0.4)$ & $(0.382)$ & $(0.387)$ & $(0.387)$ \\
\hline \multirow[t]{2}{*}{ Share of construction } & & & & -0.194 & -0.284 & 0.189 & 0.192 & 0.207 \\
\hline & & & & $(0.452)$ & $(0.463)$ & $(0.43)$ & $(0.429)$ & $(0.432)$ \\
\hline \multirow{2}{*}{$\begin{array}{l}\% \text { of dismissal lawsuits analized (+) by professional } \\
\text { judges over total }\end{array}$} & & & & & 0.0235 & 0.0299 & 0.0297 & 0.0278 \\
\hline & & & & & $(0.0253)$ & $(0.021)$ & $(0.0208)$ & $(0.0212)$ \\
\hline \multirow[t]{2}{*}{ Proportion of temporary postings at the labor courts } & & & & & $-0.0102 *$ & -0.0014 & -0.0015 & -0.0016 \\
\hline & & & & & $(0.0054)$ & $(0.0052)$ & $(0.0052)$ & $(0.0066)$ \\
\hline \multirow{2}{*}{ Judicial congestion rate (dismissals lawsuits) } & & & & & & $0.0567 * * *$ & $0.0566^{* * *}$ & $0.0563^{* * *}$ \\
\hline & & & & & & $(0.0113)$ & $(0.0113)$ & $(0.0114)$ \\
\hline \multirow[t]{2}{*}{ Judicial congestion rate (pre-trial conciliations) } & & & & & & & -0.0003 & -0.0003 \\
\hline & & & & & & & $(0.0006)$ & $(0.0006)$ \\
\hline \multirow[t]{2}{*}{ Constant } & $0.471^{* * *}$ & $0.434 * * *$ & $0.124 * *$ & $0.746^{* *}$ & $0.733^{* *}$ & $0.682 * *$ & $0.683^{* *}$ & $0.655^{* *}$ \\
\hline & $(0.0031)$ & $(0.0020)$ & $(0.0601)$ & $(0.305)$ & $(0.305)$ & $(0.286)$ & $(0.285)$ & $(0.286)$ \\
\hline Provincial fixed effects & YES & YES & YES & YES & YES & YES & YES & YES \\
\hline Observations & 2,000 & 2,000 & 2,000 & 2,000 & 2,000 & 1,800 & 1,800 & 1,728 \\
\hline R-squared & 0.052 & 0.292 & 0.337 & 0.357 & 0.365 & 0.457 & 0.457 & 0.453 \\
\hline Clusters (provinces) & 50 & 50 & 50 & 50 & 50 & 50 & 50 & 48 \\
\hline 2012 interaction with bootstrap estimation & -0.12 & $0.500^{* * *}$ & $0.408 * *$ & $0.287^{*}$ & 0.248 & 0.0665 & 0.0703 & 0.103 \\
\hline Bootstrap (standard errors) for "2012 interaction" & $(0.1240)$ & $(0.1542)$ & $(0.1597)$ & $(0.1681)$ & $(0.1716)$ & $(0.1975)$ & $(0.1857)$ & $(0.1990)$ \\
\hline
\end{tabular}


Table 17:

\begin{tabular}{|c|c|c|c|c|c|c|c|}
\hline \multicolumn{8}{|c|}{ OLS LINEAR REGRESSION } \\
\hline MODEL & 1 & 2 & 3 & 4 & 5 & 6 & $\begin{array}{l}7 \text { (excluding } \\
\text { Madrid and } \\
\text { Barcelona) }\end{array}$ \\
\hline DEPENDENT VARIABLE & \multicolumn{7}{|c|}{ Judicial congestion rate (dismissals lawsuits) } \\
\hline 2010 reform & $\begin{array}{l}0.715^{* * *} \\
(0.0806)\end{array}$ & $\begin{array}{l}0.335 * * * \\
(0.0523)\end{array}$ & $\begin{array}{l}0.338^{* * *} \\
(0.0521)\end{array}$ & $\begin{array}{l}0.299 * * * \\
(0.0503)\end{array}$ & $\begin{array}{l}0.298 * * * \\
(0.0514)\end{array}$ & $\begin{array}{l}0.635 * * * \\
(0.0957)\end{array}$ & $\begin{array}{l}0.624 * * * \\
(0.0991)\end{array}$ \\
\hline Difference in unemployment rate & & $\begin{array}{c}2.351^{* * *} \\
(0.61)\end{array}$ & $\begin{array}{l}1.777 \\
(1.08)\end{array}$ & $\begin{array}{l}0.878 \\
(0.94)\end{array}$ & $\begin{array}{c}0.768 \\
(0.972)\end{array}$ & $\begin{array}{c}0.993 \\
(0.961)\end{array}$ & $\begin{array}{c}1.017 \\
(0.973)\end{array}$ \\
\hline Temporary employment rate & & & $\begin{array}{l}-0.977 \\
(1.034)\end{array}$ & $\begin{array}{c}-0.66 \\
(1.109)\end{array}$ & $\begin{array}{r}-0.465 \\
(1.027)\end{array}$ & $\begin{array}{r}-0.555 \\
(1.017)\end{array}$ & $\begin{array}{l}-0.616 \\
(1.049)\end{array}$ \\
\hline Share of services & & & & 0.117 & $\begin{array}{c}0.0321 \\
(1.3)\end{array}$ & $\begin{array}{c}0.087 \\
(1.294)\end{array}$ & $\begin{array}{r}0.0645 \\
(1.307)\end{array}$ \\
\hline Share of industry & & & & $\begin{array}{c}-0.608 \\
(1.588)\end{array}$ & $\begin{array}{l}-0.604 \\
(1.566)\end{array}$ & $\begin{array}{c}-0.884 \\
(1.587)\end{array}$ & $\begin{array}{c}-0.917 \\
(1.604)\end{array}$ \\
\hline Share of construction & & & & $\begin{array}{l}-3.04 \\
(2.049)\end{array}$ & $\begin{array}{l}-4.151^{*} \\
(2.144)\end{array}$ & $\begin{array}{l}-4.159 * \\
(2.144)\end{array}$ & $\begin{array}{l}-4.082^{*} \\
(2.157)\end{array}$ \\
\hline $\begin{array}{c}\% \text { of dismissal lawsuits analized }(+) \text { by professional } \\
\text { judges over total }\end{array}$ & & & & & -0.0178 & -0.0478 & -0.0786 \\
\hline & & & & & $(0.133)$ & $(0.13)$ & $(0.133)$ \\
\hline Proportion of temporary postings at the labor courts & & & & & -0.0608 & -0.0611 & $-0.105^{* *}$ \\
\hline & & & & & $(0.0375)$ & $(0.0382)$ & $(0.0411)$ \\
\hline Judicial congestion rate (pre-trial conciliations) & & & & & & $\begin{array}{c}0.0066 \\
(0.0051)\end{array}$ & $\begin{array}{c}0.0064 \\
(0.0051)\end{array}$ \\
\hline Constant & $\begin{array}{c}1.895^{* * *} \\
(0.012)\end{array}$ & $\begin{array}{l}2.140^{* * *} \\
(0.0193)\end{array}$ & $\begin{array}{c}2.420 * * * \\
(0.292)\end{array}$ & $\begin{array}{l}2.689 * * \\
(1.327)\end{array}$ & $\begin{array}{l}2.828^{* *} \\
(1.364)\end{array}$ & $\begin{array}{l}2.508^{*} \\
(1.331)\end{array}$ & $\begin{array}{l}2.573^{*} \\
(1.345)\end{array}$ \\
\hline Provincial fixed effects & YES & YES & YES & YES & YES & YES & YES \\
\hline Observations & 3,348 & 1,800 & 1,800 & 1,800 & 1,800 & 1,800 & 1,728 \\
\hline R-squared & 0.145 & 0.13 & 0.132 & 0.135 & 0.162 & 0.167 & 0.162 \\
\hline Clusters (provinces) & 50 & 50 & 50 & 50 & 50 & 50 & 48 \\
\hline 2010 reform with bootstrap estimation & $0.715^{* * *}$ & $0.335^{* * *}$ & $0.338^{* * *}$ & $0.299 * * *$ & $0.298 * * *$ & $0.635 * * *$ & $0.624 * * *$ \\
\hline Bootstrap (standard errors) for "2010 reform" & $(0.0611)$ & $(0.0389)$ & $(0.0403)$ & $(0.0369)$ & $(0.0390)$ & $(0.0704)$ & $(0.0702)$ \\
\hline
\end{tabular}


Table 18:

\begin{tabular}{|c|c|c|c|c|c|c|c|}
\hline \multicolumn{8}{|c|}{ OLS LINEAR REGRESSION } \\
\hline MODEL & 1 & 2 & 3 & 4 & 5 & 6 & $\begin{array}{l}7 \text { (excluding Madrid } \\
\text { and Barcelona) }\end{array}$ \\
\hline DEPENDENT VARIABLE & \multicolumn{7}{|c|}{ Judicial congestion rate (dismissals lawsuits) } \\
\hline 2012 reform & $\begin{array}{c}1.147^{* * *} \\
(0.131)\end{array}$ & $\begin{array}{l}0.696 * * * \\
(0.0914)\end{array}$ & $\begin{array}{l}0.705 * * * \\
(0.0898)\end{array}$ & $\begin{array}{l}0.695 * * * \\
(0.0874)\end{array}$ & $\begin{array}{l}0.697 * * * \\
(0.0864)\end{array}$ & $\begin{array}{c}0.682 * * * \\
(0.0856)\end{array}$ & $\begin{array}{l}0.672^{* * *} \\
(0.0891)\end{array}$ \\
\hline Difference in unemployment rate & & $\begin{array}{c}2.626 * * * \\
(0.554)\end{array}$ & $\begin{array}{l}1.887^{*} \\
(1.012)\end{array}$ & $\begin{array}{c}0.346 \\
(0.867)\end{array}$ & $\begin{array}{c}0.195 \\
(0.914)\end{array}$ & $\begin{array}{l}-0.0911 \\
(0.914)\end{array}$ & $\begin{array}{l}-0.0531 \\
(0.925)\end{array}$ \\
\hline Temporary employment rate & & & $\begin{array}{l}-1.255 \\
(1.011)\end{array}$ & $\begin{array}{c}-0.702 \\
(1.078)\end{array}$ & $\begin{array}{c}-0.501 \\
(0.999)\end{array}$ & $\begin{array}{l}-0.558 \\
(0.994)\end{array}$ & $\begin{array}{c}-0.601 \\
(1.028)\end{array}$ \\
\hline Share of services & & & & $\begin{array}{c}0.813 \\
(1.376)\end{array}$ & $\begin{array}{c}0.719 \\
(1.388)\end{array}$ & $\begin{array}{l}0.563 \\
(1.33)\end{array}$ & $\begin{array}{l}0.531 \\
(1.34)\end{array}$ \\
\hline Share of industry & & & & $\begin{array}{r}-0.989 \\
(1.578)\end{array}$ & $\begin{array}{c}-0.99 \\
(1.547)\end{array}$ & $\begin{array}{c}-0.772 \\
(1.586)\end{array}$ & $\begin{array}{l}-0.766 \\
(1.603)\end{array}$ \\
\hline Share of construction & & & & $\begin{array}{l}-3.444^{*} \\
(2.045)\end{array}$ & $\begin{array}{l}-4.557^{* *} \\
(2.115)\end{array}$ & $\begin{array}{l}-4.301^{*} \\
(2.207)\end{array}$ & $\begin{array}{l}-4.254^{*} \\
(2.219)\end{array}$ \\
\hline$\%$ of dismissal lawsuits analized $(+)$ by & & & & & -0.0472 & -0.0446 & -0.0659 \\
\hline & & & & & $(0.124)$ & $(0.123)$ & $(0.127)$ \\
\hline $\begin{array}{l}\text { Proportion of temporary postings at the labor } \\
\text { courts }\end{array}$ & & & & & -0.0403 & -0.0421 & $-0.0728^{*}$ \\
\hline & & & & & $(0.0332)$ & $(0.0326)$ & $(0.0385)$ \\
\hline Judicial congestion rate (pre-trial conciliations) & & & & & & -0.001 & -0.0009 \\
\hline & & & & & & $(0.0035)$ & $(0.0035)$ \\
\hline Constant & $\begin{array}{l}1.950 * * * \\
(0.0059)\end{array}$ & $\begin{array}{l}2.180^{* * *} \\
(0.0107)\end{array}$ & $\begin{array}{c}2.539 * * * \\
(0.286)\end{array}$ & $\begin{array}{l}2.372^{*} \\
(1.375)\end{array}$ & $\begin{array}{c}2.534^{*} \\
(1.415)\end{array}$ & $\begin{array}{l}2.648^{*} \\
(1.367)\end{array}$ & $\begin{array}{l}2.696 * \\
(1.383)\end{array}$ \\
\hline Provincial fixed effects & YES & YES & YES & YES & YES & YES & YES \\
\hline Observations & 3,348 & 1,800 & 1,800 & 1,800 & 1,800 & 1,800 & 1,728 \\
\hline R-squared & 0.126 & 0.161 & 0.163 & 0.17 & 0.197 & 0.198 & 0.192 \\
\hline Clusters (provinces) & 50 & 50 & 50 & 50 & 50 & 50 & 48 \\
\hline 2012 reform with bootstrap estimation & $1.147 * * *$ & $0.696 * * *$ & $0.705^{* * *}$ & $0.695^{* * *}$ & $0.697 * * *$ & $0.682 * * *$ & $0.672 * * *$ \\
\hline Bootstrap (standard errors) for "2012 reform" & $(0.1131)$ & $(0.0733)$ & $(0.0660)$ & $(0.0687)$ & $(0.0656)$ & $(0.0630)$ & $(0.0670)$ \\
\hline
\end{tabular}


Table 19:

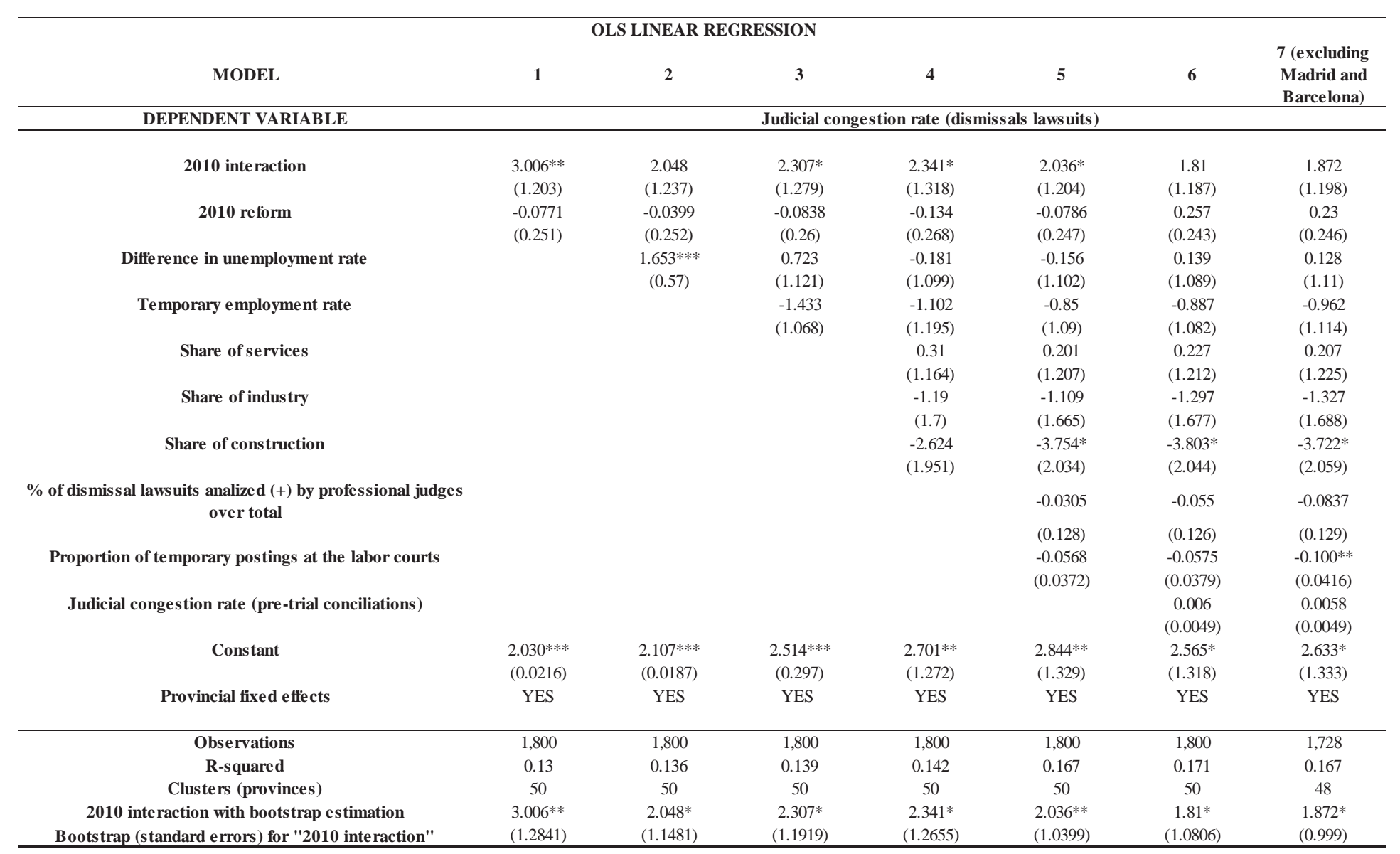




\section{Table 20:}

\begin{tabular}{|c|c|c|c|c|c|c|c|}
\hline \multicolumn{8}{|c|}{ OLS LINEAR REGRESSION } \\
\hline MODEL & 1 & 2 & 3 & 4 & 5 & 6 & $\begin{array}{c}7 \text { (excluding } \\
\text { Madrid and } \\
\text { Barcelona) }\end{array}$ \\
\hline DEPENDENT VARIABLE & \multicolumn{7}{|c|}{ Judicial congestion rate (dismissals lawsuits) } \\
\hline 2012 interaction & $\begin{array}{c}2.251 \\
(1.744)\end{array}$ & $\begin{array}{c}1.074 \\
(1.708)\end{array}$ & $\begin{array}{l}1.227 \\
(1.73)\end{array}$ & $\begin{array}{l}1.483 \\
(1.77)\end{array}$ & $\begin{array}{c}1.223 \\
(1.666)\end{array}$ & $\begin{array}{c}1.435 \\
(1.637)\end{array}$ & $\begin{array}{l}1.549 \\
(1.66)\end{array}$ \\
\hline 2012 reform & 0.436 & 0.44 & 0.413 & 0.342 & 0.406 & 0.338 & 0.298 \\
\hline Difference in unemployment rate & & $\begin{array}{c}2.561 * * * \\
(0.539)\end{array}$ & $\begin{array}{c}1.771^{*} \\
(1.006)\end{array}$ & $\begin{array}{c}0.158 \\
(0.901)\end{array}$ & $\begin{array}{l}0.0357 \\
(0.949)\end{array}$ & $\begin{array}{c}-0.323 \\
(0.936)\end{array}$ & $\begin{array}{l}-0.303 \\
(0.952)\end{array}$ \\
\hline Temporary employment rate & & & $\begin{array}{l}-1.326 \\
(1.018)\end{array}$ & $\begin{array}{c}-0.78 \\
(1.101)\end{array}$ & $\begin{array}{r}-0.566 \\
(1.017)\end{array}$ & $\begin{array}{c}-0.642 \\
(1.012)\end{array}$ & $\begin{array}{c}-0.69 \\
(1.045)\end{array}$ \\
\hline Share of services & & & & $\begin{array}{r}0.835 \\
(1.362)\end{array}$ & 0.737 & 0.56 & 0.527 \\
\hline Share of industry & & & & $\begin{array}{c}-1.241 \\
(1.737)\end{array}$ & $\begin{array}{c}-1.199 \\
(1.686)\end{array}$ & $\begin{array}{c}-0.982 \\
(1.699)\end{array}$ & $\begin{array}{c}-0.991 \\
(1.716)\end{array}$ \\
\hline Share of construction & & & & $\begin{array}{l}-3.463^{*} \\
(2.055)\end{array}$ & $\begin{array}{c}-4.563 * * \\
(2.125)\end{array}$ & $\begin{array}{c}-4.269^{*} \\
(2.2)\end{array}$ & $\begin{array}{l}-4.219 * \\
(2.213)\end{array}$ \\
\hline $\begin{array}{c}\% \text { of dismissal lawsuits analized (+) by professional } \\
\text { judges over total }\end{array}$ & & & & & -0.052 & -0.0499 & -0.071 \\
\hline & & & & & $(0.121)$ & $(0.12)$ & $(0.124)$ \\
\hline Proportion of temporary postings at the labor courts & & & & & -0.0373 & -0.0388 & $-0.0683 *$ \\
\hline Judicial congestion rate (pre-trial conciliations) & & & & & $(0.0335)$ & $\begin{array}{l}(0.0328) \\
-0.0013 \\
(0.0034)\end{array}$ & $\begin{array}{l}(0.0391) \\
-0.0011 \\
(0.0034)\end{array}$ \\
\hline Constant & $\begin{array}{l}2.109 * * * \\
(0.0103)\end{array}$ & $\begin{array}{c}2.178 * * * \\
(0.01)\end{array}$ & $\begin{array}{l}2.558 * * * \\
(0.288)\end{array}$ & $\begin{array}{l}2.420^{*} \\
(1.403)\end{array}$ & $\begin{array}{l}2.576^{*} \\
(1.438)\end{array}$ & $\begin{array}{l}2.715^{*} \\
(1.393)\end{array}$ & $\begin{array}{l}2.768^{*} \\
(1.407)\end{array}$ \\
\hline Provincial fixed effects & YES & YES & YES & YES & YES & YES & YES \\
\hline Observations & 1,800 & 1,800 & 1,800 & 1,800 & 1,800 & 1,800 & 1,728 \\
\hline R-squared & 0.13 & 0.162 & 0.164 & 0.171 & 0.198 & 0.199 & 0.193 \\
\hline Clusters (provinces) & 50 & 50 & 50 & 50 & 50 & 50 & 48 \\
\hline 2012 interaction with bootstrap estimation & 2.251 & 1.074 & 1.227 & 1.483 & 1.223 & 1.435 & 1.549 \\
\hline
\end{tabular}




\section{BANCO DE ESPAÑA PUBLICATIONS}

\section{WORKING PAPERS}

1301 JAMES COSTAIN and ANTON NAKOV: Logit price dynamics.

1302 MIGUEL GARCÍA-POSADA: Insolvency institutions and efficiency: the Spanish case.

1303 MIGUEL GARCÍA-POSADA and JUAN S. MORA-SANGUINETTI: Firm size and judicial efficacy: evidence for the new civil procedures in Spain.

1304 MAXIMO CAMACHO and GABRIEL PEREZ-QUIROS: Commodity prices and the business cycle in Latin America: living and dying by commodities?

1305 CARLOS PÉREZ MONTES: Estimation of regulatory credit risk models.

1306 FERNANDO LÓPEZ VICENTE: The effect of foreclosure regulation: evidence for the US mortgage market at state level.

1307 ENRIQUE MORAL-BENITO and LUIS SERVEN: Testing weak exogeneity in cointegrated panels.

1308 EMMA BERENGUER, RICARDO GIMENO and JUAN M. NAVE: Term structure estimation, liquidity-induced heteroskedasticity and the price of liquidity risk.

1309 PABLO HERNÁNDEZ DE COS and ENRIQUE MORAL-BENITO: Fiscal multipliers in turbulent times: the case of Spain.

1310 SAMUEL HURTADO: DSGE models and the Lucas critique.

1311 HENRIQUE S. BASSO and JAMES COSTAIN: Fiscal delegation in a monetary union with decentralized public spending

1312 MAITE BLÁZQUEZ CUESTA and SANTIAGO BUDRÍA: Does income deprivation affect people's mental well-being?

1313 ENRIQUE ALBEROLA, ÁNGEL ESTRADA and DANIEL SANTABÁRBARA: Growth beyond imbalances. Sustainable growth rates and output gap reassessment.

1314 CARMEN BROTO and GABRIEL PEREZ-QUIROS: Disentangling contagion among sovereign CDS spreads during the European debt crisis.

1315 MIGUEL GARCÍA-POSADA and JUAN S. MORA-SANGUINETTI: Are there alternatives to bankruptcy? A study of small business distress in Spain.

1316 ROBERTO RAMOS and ENRIQUE MORAL-BENITO: Agglomeration matters for trade.

1317 LAURA HOSPIDO and GEMA ZAMARRO: Retirement patterns of couples in Europe.

1318 MAXIMO CAMACHO, GABRIEL PEREZ-QUIROS and PILAR PONCELA: Short-term forecasting for empirical economists. A survey of the recently proposed algorithms.

1319 CARLOS PÉREZ MONTES: The impact of interbank and public debt markets on the competition for bank deposits.

1320 OLYMPIA BOVER, JOSE MARIA CASADO, SONIA COSTA, PHILIP DU CAJU, YVONNE MCCARTHY, EVA SIERMINSKA, PANAGIOTA TZAMOURANI, ERNESTO VILLANUEVA and TIBOR ZAVADIL: The distribution of debt across euro area countries: the role of Individual characteristics, institutions and credit conditions.

1321 BRINDUSA ANGHEL, SARA DE LA RICA and AITOR LACUESTA: Employment polarisation in Spain over the course of the 1997-2012 cycle.

1322 RODOLFO G. CAMPOS and ILIANA REGGIO: Measurement error in imputation procedures.

1323 PABLO BURRIEL and MARÍA ISABEL GARCÍA-BELMONTE: Meeting our DESTINY. A Disaggregated €uro area Short Term Indicator model to forecast GDP (Y) growth.

1401 TERESA SASTRE and FRANCESCA VIANI: Countries' safety and competitiveness, and the estimation of current account misalignments.

1402 FERNANDO BRONER, ALBERTO MARTIN, AITOR ERCE and JAUME VENTURA: Sovereign debt markets in turbulent times: creditor discrimination and crowding-out effects.

1403 JAVIER J. PÉREZ and ROCÍO PRIETO: The structure of sub-national public debt: liquidity vs credit risks.

1404 BING XU, ADRIAN VAN RIXTEL and MICHIEL VAN LEUVENSTEIJN: Measuring bank competition in China: a comparison of new versus conventional approaches applied to loan markets.

1405 MIGUEL GARCÍA-POSADA and JUAN S. MORA-SANGUINETTI: Entrepreneurship and enforcement institutions: disaggregated evidence for Spain.

1406 MARIYA HAKE, FERNANDO LÓPEZ-VICENTE and LUIS MOLINA: Do the drivers of loan dollarisation differ between CESEE and Latin America? A meta-analysis.

1407 JOSÉ MANUEL MONTERO and ALBERTO URTASUN: Price-cost mark-ups in the Spanish economy: a microeconomic perspective.

1408 FRANCISCO DE CASTRO, FRANCISCO MARTÍ, ANTONIO MONTESINOS, JAVIER J. PÉREZ and A. JESÚS SÁNCHEZ-FUENTES: Fiscal policies in Spain: main stylised facts revisited. 
1409 MARÍA J. NIETO: Third-country relations in the Directive establishing a framework for the recovery and resolution of credit institutions.

1410 ÓSCAR ARCE and SERGIO MAYORDOMO: Short-sale constraints and financial stability: evidence from the Spanish market.

1411 RODOLFO G. CAMPOS and ILIANA REGGIO: Consumption in the shadow of unemployment.

1412 PAUL EHLING and DAVID HAUSHALTER: When does cash matter? Evidence for private firms.

1413 PAUL EHLING and CHRISTIAN HEYERDAHL-LARSEN: Correlations.

1414 IRINA BALTEANU and AITOR ERCE: Banking crises and sovereign defaults in emerging markets: exploring the links.

1415 ÁNGEL ESTRADA, DANIEL GARROTE, EVA VALDEOLIVAS and JAVIER VALLÉS: Household debt and uncertainty: private consumption after the Great Recession.

1416 DIEGO J. PEDREGAL, JAVIER J. PÉREZ and A. JESÚS SÁNCHEZ-FUENTES: A toolkit to strengthen government budget surveillance.

1417 J. IGNACIO CONDE-RUIZ, and CLARA I. GONZÁLEZ: From Bismarck to Beveridge: the other pension reform in Spain.

1418 PABLO HERNÁNDEZ DE COS, GERRIT B. KOESTER, ENRIQUE MORAL-BENITO and CHRISTIANE NICKEL: Signalling fiscal stress in the euro area: a country-specific early warning system.

1419 MIGUEL ALMUNIA and DAVID LÓPEZ-RODRÍGUEZ: Heterogeneous responses to effective tax enforcement: evidence from Spanish firms.

1420 ALFONSO R. SÁNCHEZ: The automatic adjustment of pension expenditures in Spain: an evaluation of the 2013 pension reform

1421 JAVIER ANDRÉS, ÓSCAR ARCE and CARLOS THOMAS: Structural reforms in a debt overhang.

1422 LAURA HOSPIDO and ENRIQUE MORAL-BENITO: The public sector wage premium in Spain: evidence from longitudinal administrative data.

1423 MARÍA DOLORES GADEA-RIVAS, ANA GÓMEZ-LOSCOS and GABRIEL PÉREZ-QUIRÓS: The Two Greatest. Great Recession vs. Great Moderation.

1424 ENRIQUE MORAL-BENITO and OLIVER ROEHN: The impact of financial (de)regulation on current account balances

1425 MÁXIMO CAMACHO and JAIME MARTÍNEZ-MARTÍN: Real-time forecasting US GDP from small-scale factor models.

1426 ALFREDO MARTÍN OLIVER, SONIA RUANO PARDO and VICENTE SALAS FUMÁS: Productivity and welfare: an application to the Spanish banking industry.

1427 JAVIER ANDRÉS and PABLO BURRIEL: Inflation dynamics in a model with firm entry and (some) heterogeneity.

1428 CARMEN BROTO and LUIS MOLINA: Sovereign ratings and their asymmetric response to fundamentals.

1429 JUAN ÁNGEL GARCÍA and RICARDO GIMENO: Flight-to-liquidity flows in the euro area sovereign debt crisis.

1430 ANDRE LEMELIN, FERNANDO RUBIERA-MOROLLÓN and ANA GÓMEZ-LOSCOS: Measuring urban agglomeration. A refoundation of the mean city-population size index.

1431 LUIS DÍEZ-CATALÁN and ERNESTO VILLANUEVA: Contract staggering and unemployment during the Great Recession: evidence from Spain.

1501 LAURA HOSPIDO and EVA MORENO-GALBIS: The Spanish productivity puzzle in the Great Recession.

1502 LAURA HOSPIDO, ERNESTO VILLANUEVA and GEMA ZAMARRO: Finance for all: the impact of financial literacy training in compulsory secondary education in Spain.

1503 MARIO IZQUIERDO, JUAN F. JIMENO and AITOR LACUESTA: Spain: from immigration to emigration?

1504 PAULINO FONT, MARIO IZQUIERDO and SERGIO PUENTE: Real wage responsiveness to unemployment in Spain: asymmetries along the business cycle.

1505 JUAN S. MORA-SANGUINETTI and NUNO GAROUPA: Litigation in Spain 2001-2010: Exploring the market for legal services.

1506 ANDRES ALMAZAN, ALFREDO MARTÍN-OLIVER and JESÚS SAURINA: Securitization and banks' capital structure.

1507 JUAN F. JIMENO, MARTA MARTÍNEZ-MATUTE and JUAN S. MORA-SANGUINETTI: Employment protection legislation and labor court activity in Spain.

BANCODEESPAÑA

Eurosistema
Unidad de Servicios Auxiliares

Alcalá, 48 - 28014 Madrid

E-mail: publicaciones@bde.es www.bde.es 